\title{
Production and evaluation of novel functional extruded corn snacks fortified with ginger, bay leaves and turmeric powder
}

\author{
Sara Adel Amer ${ }^{*}$ (D) and Ayat Ebrahim Rizk
}

\begin{abstract}
Extruded corn snacks are accepted by all human ages especially children, but they have low functional value. Therefore, corn extruded snacks contain rich nutraceuticals dried herbs including Laurus nobilis (T1), Curcuma longa (T2), Zingiber officinale Roscoe (T3), and the mixture of these herbs (T4) were manufactured and analyzed. The results declared that all the herbal extruded corn snacks had significantly higher ash, fibers, minerals, and vitamins A and B6. For minerals, the highest percent of increase compared to control was achieved by Fe, K, Ca, Zn content in order, being the highest in T4. The contents of Vitamin A and B6 were ranged from 283 to $445 \mathrm{IU} / 100 \mathrm{~g}$ and from 0.01 to $0.08 \mathrm{mg} / 100 \mathrm{~g}$ for the herbal extrudates, respectively. The increased percent in herbal corn snacks relative to control ranged from 743 to $452 \%, 188$ to 17.6\%, and from 313 to $99 \%$ for total phenolics, flavonoids, and antioxidant activity. Besides, the highest number of phenolic compounds was recorded in T4. Despite the fact that approximately all herbal extruded products had good texture and color characteristics, the best formulation was T2 and T4 corn snacks. Furthermore, the extruded products were microbiologically safe for up to 9 months. The formulation of herbal-corn snacks could fulfill consumers' requirement for ready-to-eat-healthy foods with acceptable sensory attributes and also economically suitable for the food industry.
\end{abstract}

Keywords: Ginger, Laurel, Turmeric, Extrusion, Corn snacks, functional foods

\section{Introduction}

The progress in food products has provided information about the urgent needs of nutrients for humans. Food manufacturers are creating innovative food products that form part of the next generation of food that not only are ready for immediate use, but also have a special nutritional value (Shah et al. 2019). Extrusion technique may be utilized to make a wide range of food items with lower processing costs, continuous production, high throughputs, and superior product quality while utilizing less energy

\footnotetext{
* Correspondence: dsaramer55@yahoo.com

Special Food and Nutrition Research Department, Food Technology Research Institute. Agricultural Research Center, 9 Gamaa Street, Giza, Egypt
}

(Prabha et al. 2021). Hence, extrusion cooking is considered an economical procedure that uses hightemperature and short-time technology (HTST) with low cost and reliability (Grasso 2020). In this extrusion process, the cooking temperature should be as high as $180-190^{\circ} \mathrm{C}$; residence time is usually $20-40$ s. These conditions during extrusion result in gelatinization of starch, denaturation of protein, inactivation of raw food enzymes, diminishing of microbial counts in the final product, and destruction of naturally occurring toxic substances like aflatoxin (Saalia \& Phillips 2011). Extruded products are also gaining wide acceptability among all human ages. But the traditionally known corn extruded snacks are

(c) The Author(s). 2022 Open Access This article is licensed under a Creative Commons Attribution 4.0 International License, which permits use, sharing, adaptation, distribution and reproduction in any medium or format, as long as you give

appropriate credit to the original author(s) and the source, provide a link to the Creative Commons licence, and indicate if changes were made. The images or other third party material in this article are included in the article's Creative Commons licence, unless indicated otherwise in a credit line to the material. If material is not included in the article's Creative Commons licence and your intended use is not permitted by statutory regulation or exceeds the permitted use, you will need to obtain permission directly from the copyright holder. To view a copy of this licence, visit http://creativecommons.org/licenses/by/4.0/. 
considered unhealthy due to their poor nutritional content. Since the extrusion enables the combining of different ingredients, it is also ideal for the creation of new functional foods (Shah et al. 2019). According to Who (2019), functional foods are any natural food popularly believed to promote good health by containing vital nutrients. Functional foods also include any food types enhanced by additives like cereals, bread, or beverages that are fortified with vitamins and herbs. Many lowcost but valuable medicinal herbs are easily available and are very useful due to their nutraceutical properties. Herbs not only enhance the taste and flavour of foods but their antimicrobial and antifungal properties also help to increase the shelf life (Salmerón-Manzano et al. 2020).

Laurus nobilis belongs to the Lauraceae family and is commonly known as a sweet bay but locally known as Alghar. Recent studies have shown that $L$. nobilis seed and leaf essential oils have narcotic, antibacterial, fungicidal, gastroprotective, antinociceptive, antidiabetic cytotoxic, anti-inflammatory and trypanocidal properties (Dadalioglu \& Evrendilek 2004, Mohammed et al. 2021).

For its flavouring and digestive characteristics, turmeric (Curcuma longa) is extensively consumed. Curcumin, a phenolic yellow pigment is the key active component of turmeric. It has been traditionally used for centuries as a remedy for various disorders including the common cold, wounds, ulcers and liver disease (Raduly et al. 2021). Also a number of studies have found that it can offer substantial benefits in a number of diseases, including heart disorders, diabetes, rheumatoid arthritis, Alzheimer's disease, inflammatory bowel illness, liver fibrosis and cirrhosis, HIV, pancreatitis, malaria and it is also reported to be a safe chemopreventive agent that are able to suppress cancer metastasis (Hewlings \& Kalman 2017; Joe et al. 2004).

On the other hand, Zingiber officinale Roscoe, generally regarded as ginger, has been mostly utilized as both a seasoning and an herbal remedy across the world. It is considered one of the pungent taste herbs which contribute to the Zingiberaceae family. It has proven to display several therapeutic effects like antiplatelet antioxidant, anti-inflammatory, antimicrobial, antitumor and function (Karuppiah \& Rajaram 2012; Mao et al. 2019).

This research, therefore, aimed to develop a new type of value-added extruded corn snacks through incorporating the above-mentioned herbs namely $L$. nobilis, $C$. longa and $Z$. officinale, which could provide consumers with various functional benefits. The nutritional, functional and physicochemical characteristics of these products were evaluated.

\section{Materials and methods}

\section{Raw materials}

Yellow corn grits (Zea mays L.), was provided from "Egypt Food Company", Quisna, Minoufiya, Egypt factory delivered in the original package. Dried turmeric (Curcuma longa), ginger (Zingiber officinale Roscoe, Zingiberacae) and bay leaf or laurel (Laurus nobilis, Lauraceae) powder were purchased from the local market of Egypt.

\section{Formulation of extruded snacks}

Dehydrated powdered herbs of were added at 1, 3 and $5 \%$ level plus a mixture of all three herbs were prepared at percent 1:1:1 and were added by percent of 1,3 and $5 \%$ to corn flour. A standardized amount of salt i.e. $2 \%$ was added to all treatments (Table 1).

\section{Development of extruded snacks}

The extruded products were prepared at "Egypt Food Company" Quisna, Minoufiya, Egypt. A snack extruder (American extrusion) with a processing capacity of $150 \mathrm{~kg}$ per hour was used. The mixtures were blended for $10 \mathrm{~min}$ before extrusion. The mixtures then were mix-fed to the extruder. Extruder conditions used a moisture content of $13 \%$ and a temperature of $180^{\circ} \mathrm{C}$ with a rotation screw speed of $700 \mathrm{rpm}$ were used for all blends. A $3 \mathrm{~mm}$ diameter die was applied. The feeding rate was approximately $3 \mathrm{~kg} / \mathrm{min}$. After that, the extrusion products were dried at $\left(115\right.$ and $\left.125^{\circ} \mathrm{C}\right)$ for 2 to $3 \mathrm{~min}$ by a pelt conveyor oven equipped with a diesel oil burner (Model 3000 Dryer American extrusion). After production, the corn snacks were cooled to room temperature $\left(24^{\circ} \mathrm{C}\right)$ and were then packed in polyethylene bags.

\section{Organoleptic evaluation of extruded snacks}

A panel of semi-trained judges (15 panelists) carried out the organoleptic estimation of the formulated products. The treatments include 4 types of extruded products. Each contains three levels of herbs plus one control (without herbs). The nine-point hedonic scale for characteristics comprised appearance, colour, texture, aroma, taste and overall acceptance was used (Lawless \& Heymann 2010). The exact composition of products was not revealed to the panelists to get their exact judgment of the samples. The mean scores for each product were then calculated.

Table 1 Percent $\%(\mathrm{w} / \mathrm{w})$ of raw blends formulation

\begin{tabular}{llll}
\hline Percent of formulation (\%) & 1 & 3 & 5 \\
Herbs alone or herbs mixture (1:1:1 from each herb type) & 1 & 3 & 5 \\
salt & 2 & 2 & 2 \\
Corn & 97 & 95 & 93 \\
\hline
\end{tabular}




\section{The proximate analysis}

The Proximate composition analysis (protein, ash, crude fiber, carbohydrates, and lipids) of both raw materials and the extruded products were estimated according to the AACC (2000).

\section{Minerals and vitamins \\ Estimation of minerals}

Macro-minerals (calcium, magnesium, potassium, sodium, and phosphorus) and trace minerals (Zinc, iron, and copper) were estimated in both raw blends and extruded products. Briefly, the prepared Ash of the samples was boiled with $10 \mathrm{~mL}$ of $20 \%$ hydrochloric acid then diluted with deionized water after filtration as described by AOAC (2005). Then Minerals was measured using the atomic absorption spectrometry (AAS, Varian model: 220FS). Whereas, phosphorus was evaluated spectrophotometrically by the molybdate technique as described by Onwuka (2005).

\section{Chromatographic determination of vitamins}

Standard vitamins including water-soluble vitamin (pyridoxine-B6), and fat-soluble vitamin (vitamin A) were obtained from Sigma-Aldrich. All extruded samples were firstly grounded to a homogenous state using a food processor. Analysis of vitamin B6 was performed using HPLC by a commercial analytical laboratory (AgriQuality New Zealand). Briefly, enzymatic hydrolysis was employed for dephosphorylating the vitamins for the analysis of pyridoxine. The detection of pyridoxine was then assayed by reversed-phase, ion-pair HPLC (Bitsch \& Möller 1989; Reitzer-Bergaentzle et al. 1993). Separation was accomplished isocratically with a mobile phase consisting of acetonitrile $/ 0-05 \mathrm{M}$ potassium dihydrogen phosphate (4:96, $\mathrm{v} / \mathrm{v}$ ) containing $0.5 \times 103 \mathrm{M}$ sodium heptane sulfonate. The mobile phase was then adjusted to $\mathrm{pH} 2.50$ with phosphoric acid and filtered through cellulose acetate filter $(0.45 / \mathrm{zm})$. The separation was performed at ambient temperature at a flow rate of $1 \mathrm{~mL} / \mathrm{min}$. The fluorometric detector ran at an excitation wavelength of $290 \mathrm{~nm}$ and at an emission wavelength of $395 \mathrm{~nm}$. For HPLC estimation of vitamin A, the saponification method provided by Dennison and Kirk (1977) was carried out. For HPLC analysis, an Eclipse $\times$ BD $-\mathrm{C} 18$ column $(4.6 \times 250$ $\mathrm{mm} 5 \mu \mathrm{m})$ was used with a linear gradient of methanol: water (95:5) at a constant flow rate of $1 \mathrm{~mL} / \mathrm{min}$ by using a binary pump with column temperature of $40{ }^{\circ} \mathrm{C}$. A multiple wavelength detector was employed for the detection of vitamins using a wavelength of $325 \mathrm{~nm}$. The true retention of the vitamin content of the extruded product was calculated according to (Bergström 1998) based on the following equation.
(Vita min content of extruded product $\times g$ extruded) $/$ (Vita min content in raw blends $\times g$ component $)$

\section{Functional properties Extraction of active compounds}

Phytochemical components were evaluated in both the extruded snacks and raw blended formula following the method of Horvat et al. (2020). Briefly, all snacks were milled and $1 \mathrm{~g}$ of each was mixed separately and homogenized with $3 \mathrm{~mL}$ of HCL in methanol (0.1\%) for $2 \mathrm{~min}$. The samples were then centrifuged $\left(5 \mathrm{~min}\right.$ at $\left.4^{\circ} \mathrm{C}\right)$ at $7168 \times \mathrm{g}$ after $60 \mathrm{~min}$ of sonication (Sonorex Digitec, Bandelin, Germany, frequency $20 \mathrm{kHz}$, power $100 \mathrm{~W}$ ). The retrieved supernatants were gathered and kept in the dark at $-20^{\circ} \mathrm{C}$ until analysis.

\section{Total phenolic content (TPC)}

The TPC in the previously collected supernatant was estimated following the technique of Singleton et al. (1999) with certain modifications. Briefly, $0.1 \mathrm{~mL}$ of the Folin-Ciocalteu phenol reagent (1:1) was mixed with 0.1 $\mathrm{mL}$ of sample or to the standard dilutions $(100-500 \mu \mathrm{g} /$ $\mathrm{mL}$ ) and $1.5 \mathrm{~mL}$ of distilled water. Upon homogenization for $5 \mathrm{~min}$, it was vortexed with $0.3 \mathrm{~mL}$ of $20 \mathrm{~g} / 100 \mathrm{~mL}$ $\mathrm{Na}_{2} \mathrm{CO}_{3}$ solution. After that, it was kept away from light for $60 \mathrm{~min}$ at the ambient temperature. Then, the absorbance of samples was read at $740 \mathrm{~nm}$ spectrophotometrically (Cary 50-Varian Inc., Walnut Creek, CA, USA) against a blank which was acidified methanol. The experiment was done in triplicate. The findings were represented as $\mathrm{mg}$ gallic acid equivalents per $\mathrm{g}$ ( $\mathrm{mg}$ $(\mathrm{GAE}) / \mathrm{g})$ of dry matter.

\section{Total flavonoids content (TFC)}

TFC was estimated following the colourimetric assay of Zhishen et al. (1999). $1 \mathrm{~mL}$ of extract solution and/or dilutions of a standard solution $(10-100 \mu \mathrm{g} / \mathrm{mL})$ was added to $4 \mathrm{~mL}$ of distilled water. $5 \mathrm{~g} / 100 \mathrm{~mL} \mathrm{NaNO} 2$ $(0.3 \mathrm{~mL})$ was applied to the latter mixture. After $5 \mathrm{~min}$, $0.3 \mathrm{~mL}$ of $10 \mathrm{~g} / 100 \mathrm{~mL} \mathrm{AlCl} 3$ was added. After $6 \mathrm{~min}, 2$ $\mathrm{mL}$ of $1 \mathrm{M} \mathrm{NaOH}$ was added. Finally dist. $\mathrm{H}_{2} \mathrm{O}$ was added to complete the overall volume to $10 \mathrm{~mL}$ and it was well blended. The absorbance of solutions was read against a freshly prepared blank at $510 \mathrm{~nm}$. The TFC was expressed as $\mathrm{mg}$ quercetin equivalents per $\mathrm{g}$ of dry matter (mg QE/g).

\section{Antioxidant activity of extruded products (AOXA)}

The AOXA of both raw blended formula and its extruded snacks was conducted in accordance with Sanchez-Moreno et al. (1998). Thus, $3.9 \mathrm{~mL}$ of DPPH (1, 1-diphenyl-2-picryl hydrazyl, $0.025 \mathrm{~g} / \mathrm{L}$ methanol) was mixed with $0.1 \mathrm{~mL}$ of each extracted sample. 
After stirring and storing in the dark place for 15 min, the absorbance was recorded at $515 \mathrm{~nm}$ against a blank. The analysis was performed in triplicates. The scavenging activity was calculated by the following equation:

Scavenging activity $(\%)=[($ Absorbance of control

-Absorbance of test sample)

/Absorbance of control] $\times 100$

\section{Chromatographic determination of polyphenolic compounds}

All Commercial standards including 21 phenolic compounds were purchased from Sigma-Aldrich (USA). Both raw blends and snacks extrudates were powdered by using a laboratory homogenizer. Briefly, phenolic compounds were extracted from $0.5 \mathrm{~g}$ of the powdered samples using $70 \%$ methanol (Sigma) on an ultrasonic bath at $70^{\circ} \mathrm{C}$ for $3 \mathrm{~h}$. Then, all samples were filtered. Each extract was evaporated to dryness. The residue was dissolved in methanol and used for HPLC analyses after filtration with a $0.45 \mu \mathrm{m}$ syringe filter. HPLC Hewllet packared (series 1050) equipped with an auto-sampling injector, solvent degasser, and quarter HP pump (series 1050). For estimation of phenolic compounds, Gradient elution by using a mobile phase of solvent A (2\% acetic acid) and solvent B $(0.5 \%$ acetic acid: acetonitrile (1:1)) was used. Whereas for flavonoids, gradient elution was done by using a mobile phase of solvent A ( $2 \%$ acetic acid), and solvent $\mathrm{B}$ (methanol) was used. The gradients of the setup according to Marchev et al., (2011). The flow rate was $1 \mathrm{~mL} / \mathrm{min}$ and the injection volume was $20 \mu \mathrm{L}$. UV absorbance was measured at $220-365 \mathrm{~nm}$. Retention time and peak area (\%) were used to identify and calculate the phenolic and flavonoids compound concentrations by comparing them with those of reference standards.

\section{Physical properties of extruded snacks Expansion ratio and bulk density (BD)}

The diameter of the snacks was taken as a mean of diameters of 15 pieces from each treatment (Alam et al. 2014). Then the expansion ratio (ER) and bulk density (BD) (g $\mathrm{cm}^{-3}$ ) of the snacks were defined according to (AlvarezMartinez et al. 1988) using the following equation:

$$
\begin{aligned}
& \mathrm{ER}=\text { snack diameter }(\mathrm{mm}) / \text { die diameter }(\mathrm{mm}) . \\
& \mathrm{BD}=4 \times \mathrm{m} / \pi \times \mathrm{D} 2 \times \mathrm{L}(2)
\end{aligned}
$$

Where $\mathrm{m}$ is the sample weight $(\mathrm{g}), \mathrm{D}$ is the diameter of each snack $(\mathrm{cm})$ and $\mathrm{L}$ is the length of the extrudate $(\mathrm{cm})$.

\section{Cross-section analysis through image $j$}

The investigation of cell properties was performed according to Lotfi Shirazi et al. (2020) with some modifications. Cross-sections were made by cutting spheres of each extruded product in the middle with a Stanley knife A. Then it was captured by a colour digital camera (AQM-LX1) with a lens focal length of 35 $\mathrm{mm}$ and was located vertically at a fixed distance. The lens aperture of 5.6, ISO 320, and a shutter speed of $1 / 80 \mathrm{~s}$ with $3840 \times 2160$ pixels were used. The image analysis was firstly managed by the Photofiltre Studio software (version X). The center of images of the snack pieces was cropped at a size of $40 \times 40 \mathrm{~mm}$ and then analysed by the ImageJ software (National Institutes of Health, USA version $1.53 \mathrm{c}$ ). The type of image was converted to grey-level (8 bits). After adjusting the contrast, the pixel scale was converted to mm by using a known length. In turn, a freehand selection tool was used to line the cells. Measurements were taken to elucidate the mean area of cells (mm2) and numbers of cells for each type of extruded product. Successively the area distribution figure was obtained.

\section{Colour analysis}

The extruded samples were grounded. Ground samples were sieved with a 60-mesh sieve to ensure a homogeneous sample. Five measurements were recorded for each sample with Chromameter (CR-400, Konica Minolta) (Singkhornart et al. 2014). The Lvalue in the colour system represented lightness with zero for darkness and 100 for lightness; a value represented the extent of green colour in the range from -100 to zero and red in the range from zero to 100 ; b-value quantifies blue in the range from 100 to zero and yellow in the range from zero to 100.

\section{Instrumental texture analysis}

A Texture Analyzer (TA.XT Plus, UK) with a $5 \mathrm{~kg}$ cell load and a cylindrical probe of $35 \mathrm{~mm}$ in diameter was used for estimating the texture features of the corn extruded sample. Parameters used in this study were: pretest speed, $1.00 \mathrm{~mm} / \mathrm{s}$; test speed, $1 \mathrm{~mm} / \mathrm{s}$; post-test speed, $2 \mathrm{~mm} / \mathrm{s}$; data processing rate, 200 points/s. Hardness was derived as the maximum peak force, measured in Newton $(\mathrm{N})$. Whereas, adhesiveness is the negative force area A3 estimated for the first bite (Mazumder et al. 2007). For calculating other parameters, the following equations were used.

Springiness is defined as how much a product physically springs back after deformed during the first pressure and could wait between the two strokes. 
$($ Springiness $)=$ Probe travel distance in second compression cycle (Dis tance 2)/ Probe travel dis tance in first compression cycle (Dis tance 1)

Gumminess $=$ Hardness $\times$ Cohesiveness

Chewiness $=$ Hardness $\times$ Cohesiveness $\times$ Springiness Resilience $=$ Up stroke energy of the first compression (Area 4)

/Down stroke energy of the first compression(Area 3)

This test was run in triplicate for each extruded

\section{Microbial analysis}

$0.5 \mathrm{~g}$ was taken from each sample for the microbiological test. Total bacterial count Agar (Biolife, USA) was utilized for counting of total count bacteria (TBC), while potato dextrose agar (Biolife, USA) was exploited for yeast and mould counts (YM). The total coliform count was done on Violet Red Bile Agar (VRBA, Biolife, USA) and incubated at $35^{\circ} \mathrm{C}$ for $48 \mathrm{~h}$. All counts were calculated as CFU/g. According to Salfinger and Tortorello, (2017), in all extruded products during storage for 9 months in a closed container. All findings were expressed as an average of three replicates.

\section{Statistical analyses}

All experiments were repeated three times and the related analysis results are expressed as average. The associated results were subjected to the analysis of variance (ANOVA) by the Statistical Analysis System SAS (2017). Duncan's multiple range analysis was used to distinguish the relevance of the discrepancy at $p<0.05$. The variation in the significance is indicated by different series of superscripts (e.g., a, ab, b,. . z). The correlation between different parameters was done with Excel.

\section{Results}

Sensory evaluation of extruded snacks

Different treatments of extruded products containing varied ratios ranging from 1 to $5 \%$ of each herb and the mixture of the three herbs (1:1:1) plus a control extruded product were organoleptic evaluated (Table 2). As can be noticed, the laurel-corn snacks gave the best odour in the lower concentrations up to $3 \%$ with desired long-lasting mouthfeel effect. While turmeric- corn snacks gave the best colour as well as flavour. The ginger treatment exhibited some spicy taste which increased with increasing the concentration, while the treatment included mixtures of herbs comprising all the flavours of its component, and it was sensory accepted at law concentration (3\%). The overall evaluation indicated that the best score is for the concentration of $3 \%$ of each herb and also of the treatment containing herb mixtures (Fig. 1).

\section{Proximate analysis}

The proximate composition of both raw components and the extruded snacks are presented in Table 3. As can be shown, there was little difference in protein content between treatments $(p>0.05)$, and this was somewhat improved relative to control after the inclusion of various herbs being the highest in T4. The moisture content of products is greatly affected by the extrusion process and its range was approximately between 5 and $6 \%$. The maximum moisture level of extruded items was for T3. The fat level was marginally modified and the

Table 2 Sensory quality score of extruded fortified corn snack

\begin{tabular}{|c|c|c|c|c|c|c|}
\hline Types of extrudates & Concentrations & Colour & Texture & Taste & Odour & Overall acceptability \\
\hline Control & 0 & $9.0 \pm 0.0^{C}$ & $9.0 \pm 0.4^{C}$ & $7.5 \pm 0.2^{F}$ & $7.0 \pm 0.1^{F}$ & $8.5 \pm 0.01^{\mathrm{E}}$ \\
\hline \multirow[t]{3}{*}{ Laurel-corn snacks } & $1 \%$ & $9.0 \pm 0.1^{\mathrm{Cb}}$ & $8.6 \pm 0.5^{\mathrm{Da}}$ & $8.3 \pm 0.4^{\mathrm{Da}}$ & $9.0 \pm 0.3^{c c}$ & $8.72 \pm 0.02^{\mathrm{Da}}$ \\
\hline & $3 \%$ & $9.2 \pm 0.1^{\mathrm{Ba}}$ & $8.4 \pm 0.3^{\mathrm{Da}}$ & $8.4 \pm 0.05^{\mathrm{Da}}$ & $9.6 \pm 0.1^{\mathrm{Aa}}$ & $8.95 \pm 0.01^{\mathrm{Da}}$ \\
\hline & $5 \%$ & $8.6 \pm 0.4^{D c}$ & $8.0 \pm 0.1^{\mathrm{Eb}}$ & $7.8 \pm 0.01^{\mathrm{EC}}$ & $9.7 \pm 0.0^{\mathrm{Aa}}$ & $8.37 \pm 0.02^{\mathrm{Ec}}$ \\
\hline \multirow[t]{3}{*}{ Ginger-corn snacks } & $1 \%$ & $9.0 \pm 0.5^{\mathrm{Ca}}$ & $8.0 \pm 0.4^{\mathrm{Fc}}$ & $8.6 \pm 0.06^{\mathrm{Db}}$ & $9.0 \pm 0.3^{\mathrm{Cc}}$ & $8.65 \pm 0.03^{D c}$ \\
\hline & $3 \%$ & $9.2 \pm 0.3^{\mathrm{Ba}}$ & $8.6 \pm 0.5^{\mathrm{Db}}$ & $9.2 \pm 0.04^{\mathrm{Ba}}$ & $9.4 \pm 0.1^{\mathrm{Bb}}$ & $9.1 \pm 0.01^{\mathrm{Ba}}$ \\
\hline & $5 \%$ & $8.2 \pm 0.1^{\mathrm{Dc}}$ & $9.1 \pm 0.1^{\mathrm{Ca}}$ & $9.0 \pm 0.02^{\mathrm{Ca}}$ & $9.6 \pm 0.0^{\mathrm{Aa}}$ & $8.79 \pm 0.01^{\mathrm{Da}}$ \\
\hline \multirow[t]{3}{*}{ Turmeric- corn snacks } & $1 \%$ & $9.0 \pm 0.5^{\mathrm{Cd}}$ & $9.4 \pm 0.1^{\mathrm{Ba}}$ & $8.2 \pm 0.01^{D C}$ & $8.8 \pm 0.01^{C c}$ & $8.85 \pm 0.01^{D c}$ \\
\hline & $3 \%$ & $9.6 \pm 0.2^{A c}$ & $9.6 \pm 0.3^{\mathrm{Aa}}$ & $9.8 \pm 0.03^{\mathrm{Aa}}$ & $9.4 \pm 0.1^{\mathrm{Ba}}$ & $9.6 \pm 0.02^{\mathrm{Aa}}$ \\
\hline & $5 \%$ & $9.8 \pm 0.4^{\mathrm{Ab}}$ & $9.8 \pm 0.1^{\mathrm{Aa}}$ & $9.0 \pm 0.04^{\mathrm{Cb}}$ & $9.5 \pm 0.2^{\mathrm{Aa}}$ & $9.52 \pm 0.02^{\mathrm{Aa}}$ \\
\hline \multirow[t]{3}{*}{ Mixed herbs- corn snacks } & $1 \%$ & $9.0 \pm 0.4^{\mathrm{Ca}}$ & $9.0 \pm 0.3^{\mathrm{Cb}}$ & $8.2 \pm 0.01^{\mathrm{Dc}}$ & $8.4 \pm 0.4^{\mathrm{Dc}}$ & $8.6 \pm 0.05^{\mathrm{Db}}$ \\
\hline & $3 \%$ & $9.2 \pm 0.5^{\mathrm{Ba}}$ & $9.4 \pm 0.1^{\mathrm{Ba}}$ & $9.2 \pm 0.04^{\mathrm{Ba}}$ & $9.2 \pm 0.3^{\mathrm{Ba}}$ & $9.25 \pm 0.03^{\mathrm{Ba}}$ \\
\hline & $5 \%$ & $9.0 \pm 0.2^{\mathrm{Ca}}$ & $9.1 \pm 0.5^{\mathrm{cb}}$ & $8.6 \pm 0.02^{\mathrm{Db}}$ & $9.3 \pm 0.2^{\mathrm{Ba}}$ & $9.0 \pm 0.04^{\mathrm{Ca}}$ \\
\hline
\end{tabular}

Values are expressed as means \pm standard deviations, $\left(A, B, C_{1} ..\right)$ donated the significance difference between all treatments in the same column for one parameter, $(a, b, c, .$.$) donated the significance different between different concentrations in same treatment under the same parameter. Means sharing similar letter$ within a column are statistically non significant $(p>.05)$ 


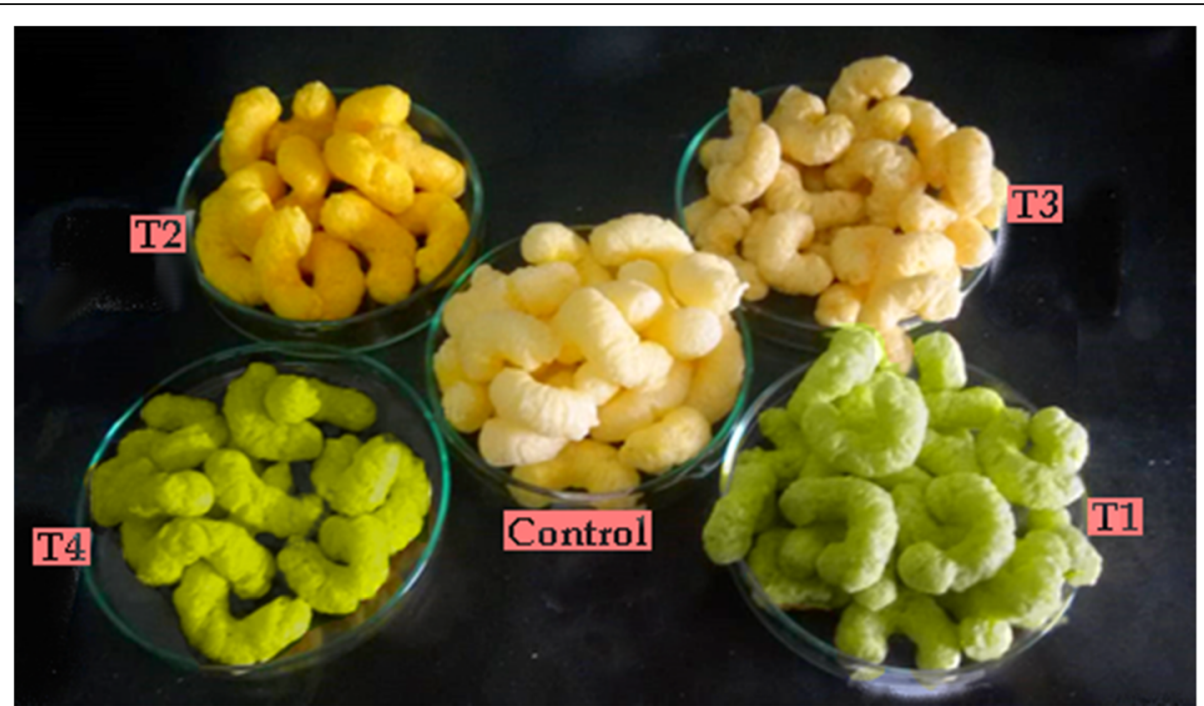

Fig. 1 Control: plain extruded product. T1, T2, T3 and T4: extruded corn product fortified with 3\% (w/w) of laurel, turmeric, ginger and mixture formula contains $3 \%$ of the three herbs' mixture mentioned (1:1:1), respectively

maximum content was in T4. While the ash content was increased significantly in the extruded products containing herbs than in the control sample being the highest in T2 and T4. As well crude fiber content was slightly raised for all treatments and the highest content was detected in the mixture treatment (T4). Meanwhile, the highest carbohydrate content was recorded by the control sample.

\section{Minerals and vitamins}

When raw blends were compared to extruded products (Table 4), it was revealed that all treatments improved in mineral content with the exception of $\mathrm{Zn}$ in control, $\mathrm{K}$ in $\mathrm{T} 1, \mathrm{Mg}$ in $\mathrm{T} 2, \mathrm{Ca}$ in control, and $\mathrm{P}$ in all treatments with the exception of T2, which exhibited a minor increase. However, when extruded products were compared to the control, there was a significant increase in mineral content (Fig. 2). Fe, $\mathrm{K}, \mathrm{Ca}$, and $\mathrm{Zn}$ had the biggest percentage rise in herbal corn snacks, ranging from 48 to $505.7 \%, 4.1$ to $497 \%, 97.05$ to $176.4 \%$, and 108.2 to $163.3 \%$, respectively. It can be shown that the contents of $\mathrm{K}, \mathrm{Ca}$, and $\mathrm{Fe}$ in $\mathrm{T} 4$ get the highest percentage of increase.

Table 5 indicates the vitamin content of extruded items, whereas Fig. 3 illustrates vitamin retention following the extrusion process. The vitamin A content of the herbal extruded items ranged from $283 \mathrm{IU}$ to $445 \mathrm{IU} /$ $100 \mathrm{~g}$. The turmeric-extruded product $\mathrm{T} 2$ has the

Table 3 Proximate analysis of raw components and extruded products (\%)

\begin{tabular}{|c|c|c|c|c|c|c|}
\hline Types & Moisture & Protein & Fat & Ash & Crude fiber & Carbohydrate \\
\hline \multicolumn{7}{|l|}{ Raw materials } \\
\hline Corn grifts & $12.6 \pm 0.12^{\mathrm{a}}$ & $8.88 \pm 0.22^{d}$ & $3.55 \pm 0.44^{\mathrm{e}}$ & $0.65 \pm 0.32^{c}$ & $2.24 \pm 0.54^{e}$ & $74.29 \pm 0.16^{\mathrm{a}}$ \\
\hline Pay leaves & $12 \pm 0.10^{b}$ & $9.8 \pm 0.20^{a}$ & $9.0 \pm 0.34^{a}$ & $3.7 \pm 0.01^{a}$ & $25 \pm 0.25^{a}$ & $65.5 \pm 0.55^{d}$ \\
\hline Turmeric & $8.9 \pm 0.02^{d}$ & $9.5 \pm 0.11^{b}$ & $6.8 \pm 0.21^{c}$ & $3.2 \pm 0.01^{b}$ & $23 \pm 0.16^{b}$ & $71.55 \pm 0.15^{c}$ \\
\hline Ginger & $9.0 \pm 0.01^{d}$ & $9.0 \pm 0.13^{c}$ & $5.6 \pm 0.30^{d}$ & $3.3 \pm 0.01^{b}$ & $13 \pm 0.65^{d}$ & $73.1 \pm 0.22^{b}$ \\
\hline Herbal mixtures & $9.8 \pm 0.02^{c}$ & $9.5 \pm 0.11^{b}$ & $7.2 \pm 0.21^{b}$ & $3.4 \pm 0.02^{b}$ & $20.5 \pm 0.33^{c}$ & $70.1 \pm 0.35^{c}$ \\
\hline \multicolumn{7}{|l|}{ Extruded products } \\
\hline Control & $5.18 \pm 0.42^{c}$ & $8.7 \pm 0.12^{b}$ & $3.45 \pm 0.01^{b c}$ & $1.62 \pm 0.52^{c}$ & $0.89 \pm 0.23^{d}$ & $81.05 \pm 0.34^{\mathrm{a}}$ \\
\hline $\mathrm{T} 1$ & $5.73 \pm 0.31^{b}$ & $8.9 \pm 0.22^{b}$ & $3.61 \pm 0.13^{b}$ & $2.8 \pm 0.11^{a}$ & $1.61 \pm 0.34^{b}$ & $78.96 \pm 0.32^{b}$ \\
\hline $\mathrm{T} 2$ & $5.8 \pm 0.32^{b}$ & $8.72 \pm 0.12^{b}$ & $3.55 \pm 0.02^{b}$ & $2.35 \pm 0.31^{b}$ & $0.99 \pm 0.11^{d}$ & $79.58 \pm 0.62^{b}$ \\
\hline T3 & $6.08 \pm 0.35^{a}$ & $8.63 \pm 0.12^{b}$ & $3.37 \pm 0.03^{c}$ & $2.4 \pm 0.43^{b}$ & $1.03 \pm 0.01^{c}$ & $80 \pm 0.63^{c}$ \\
\hline T4 & $5.73 \pm 0.31^{b}$ & $9.62 \pm 0.35^{\mathrm{a}}$ & $3.84 \pm 0.02^{\mathrm{a}}$ & $2.8 \pm 0.11^{a}$ & $1.91 \pm 0.53^{\mathrm{a}}$ & $78.01 \pm 0.23^{b}$ \\
\hline
\end{tabular}

Control: plain extruded product. T1, T2, T3 and T4: extruded product fortified with $3 \%(\mathrm{w} / \mathrm{w})$ of bay leaves, turmeric, ginger and and mixture formula contains $3 \%$ of the three herbs' mixture mentioned (1:1:1), respectively 
Table 4 Minerals composition of raw blends and extruded products ( $\mathrm{g} / 100 \mathrm{~g}$ )

\begin{tabular}{|c|c|c|c|c|c|c|c|c|}
\hline parameters & $Z n$ & $\mathrm{~K}$ & $\mathrm{Mg}$ & $\mathrm{Ca}$ & $\mathrm{Fe}$ & $P$ & $\mathrm{Na}$ & $\mathrm{Cu}$ \\
\hline \multicolumn{9}{|l|}{ Raw blends } \\
\hline Corn grifts & $0.74 \pm 0.07^{d}$ & $50.5 \pm 0.65^{\mathrm{e}}$ & $33.6 \pm 0.21^{e}$ & $40.1 \pm 0.88^{e}$ & $3.15 \pm 0.61^{\mathrm{e}}$ & $38.9 \pm 0.51^{c}$ & $20.3 \pm 0.06^{\mathrm{a}}$ & $0.08 \pm 0.01^{a}$ \\
\hline $\mathrm{T} 1$ & $0.95 \pm 0.12^{b}$ & $60.3 \pm 0.43^{c}$ & $34.8 \pm 0.34^{d}$ & $50.5 \pm 0.43^{d}$ & $3.99 \pm 0.63^{d}$ & $40.3 \pm 0.23^{b}$ & $17.5 \pm 0.34^{d}$ & $0.04 \pm 0.00^{\mathrm{a}}$ \\
\hline $\mathrm{T} 2$ & $0.99 \pm 0.0^{a}$ & $154.9 \pm 0.76^{b}$ & $42.9 \pm 0.16^{\mathrm{a}}$ & $56.2 \pm 0.62^{b}$ & $14.84 \pm 0.52^{\mathrm{a}}$ & $37.8 \pm 0.23^{d}$ & $19.4 \pm 0.11^{b}$ & $0.03 \pm 0.1^{b}$ \\
\hline T3 & $0.83 \pm 0.11^{c}$ & $55.7 \pm 0.65^{d}$ & $37.6 \pm 0.03^{c}$ & $52.8 \pm 0.55^{c}$ & $4.30 \pm 0.23^{c}$ & $38.5 \pm 0.11^{c}$ & $18.5 \pm 0.32^{\mathrm{cd}}$ & $0.07 \pm 0.01^{\mathrm{a}}$ \\
\hline T4 & $0.99 \pm 0.0^{a}$ & $271 \pm 0.77^{a}$ & $40.6 \pm 0.22^{b}$ & $66.7 \pm 0.44^{\mathrm{a}}$ & $5.73 \pm 0.11^{b}$ & $42.4 \pm 0.11^{a}$ & $18.9 \pm 0.23^{c}$ & $0.06 \pm 0.02^{a}$ \\
\hline \multicolumn{9}{|c|}{ Extruded products } \\
\hline Control & $0.49 \pm 0.02^{e}$ & $53.6 \pm 0.63^{e}$ & $35.4 \pm 0.53^{d}$ & $33.9 \pm 0.31^{\mathrm{e}}$ & $4.88 \pm 0.82^{e}$ & $32.5 \pm 0.35^{c}$ & $22.5 \pm 0.42^{\mathrm{a}}$ & $0.12 \pm 0.02^{b}$ \\
\hline $\mathrm{T} 1$ & $1.02 \pm 0.01^{d}$ & $55.8 \pm 0.53^{d}$ & $37.7 \pm 0.30^{c}$ & $66.8 \pm 0.44^{d}$ & $7.23 \pm 0.33^{d}$ & $38.3 \pm 0.33^{b}$ & $20.9 \pm 0.29^{c}$ & $0.13 \pm 0.01^{b}$ \\
\hline $\mathrm{T} 2$ & $1.08 \pm 0.02^{c}$ & $167.9 \pm 0.58^{b}$ & $39.2 \pm 0.23^{b}$ & $76.7 \pm 0.090^{c}$ & $26,01 \pm 0.43^{b}$ & $39.5 \pm 0.21^{\mathrm{a}}$ & $20.4 \pm 0.11^{c}$ & $0.11 \pm 0.00^{b}$ \\
\hline T3 & $1.18 \pm 0.04^{b}$ & $70.3 \pm 0.93^{c}$ & $38.9 \pm 0.21^{b}$ & $80.3 \pm 0.84^{b}$ & $12.56 \pm 0.15^{c}$ & $30.2 \pm 0.12^{d}$ & $21.6 \pm 0.35^{b}$ & $0.15 \pm 0.02^{b}$ \\
\hline T4 & $1.29 \pm 0.02^{\mathrm{a}}$ & $320 \pm 0.77^{\mathrm{a}}$ & $45.6 \pm 0.52^{\mathrm{a}}$ & $93.7 \pm 0.52^{\mathrm{a}}$ & $29.56 \pm 0.55^{a}$ & $30.5 \pm 0.55^{d}$ & $20.5 \pm 0.21^{c}$ & $0.19 \pm 0.01^{a}$ \\
\hline
\end{tabular}

Raw blends: blends prepared before extrusion process. Control: plain extruded product. T1, T2, T3 and T4: extruded corn product fortified with 3\% (w/w) of bay leaves, turmeric, ginger powder and mixture formula contains $3 \%$ of the three herbs' mixture mentioned (1:1:1), respectively

greatest vitamin A content with $12.29 \%$ vitamin retention percent, followed by the mixture-extruded product (335 IU) but with a retention percent of $21 \%$. The levels of vitamin B6 (Pyridoxine) in the herbal extruded preparations varied from 0.01 to $0.08 \mathrm{mg} / 100 \mathrm{~g}$. T2 extruded product had the greatest vitamin B6 content, followed by T4 extrudate, with vitamin retention of 86.21 and $75 \%$, respectively.

\section{Functional properties}

Certain functional attributes were assessed in the extruded products including overall phenolic, flavonoid contents and scavenging activity in comparison to raw blends prior to extrusion (Table 6). The extrusion process primarily resulted in a reduction in the active compounds. The loss percent is ranged from 84.5 to $14 \%$ for TPC being the highest in the control and the lowest in T2 treatment. Even though for TFC, there was an increasing percent of 32 and $7 \%$ for control and T1, respectively, the percent loss was also recorded for other treatments which were varied from 50 to $64 \%$. For AOXA, the increasing percent for control was 20\%, while the loss percent in treatments was ranged from 15 to $40 \%$ being the highest in T4 and the lowest in T1. For extruded products, the maximum TPC was recorded for T2. While the highest levels of TFC and AOXA were noted for $\mathrm{T} 1$.

The change in functional properties was also expressed as an increasing percent between the extruded items as compared to control-extruded snacks (Fig. 4). It was observed that all the parameters analysed had been improved. For TPC, the increased percent were ranging from $742.62 \%$ (T2) to $451.79 \%$ (T1), from 188.55 (T1) to $17.63 \%$ (T3) for TFC, and from 313.29 (T1) to $98.74 \%$ (T3) for AOXA.

The changes in individual phenolics before and after extrusion are presented in Table 7. HPLC detected only 10 phenolic acids in corn snacks compared to 17, 18 and

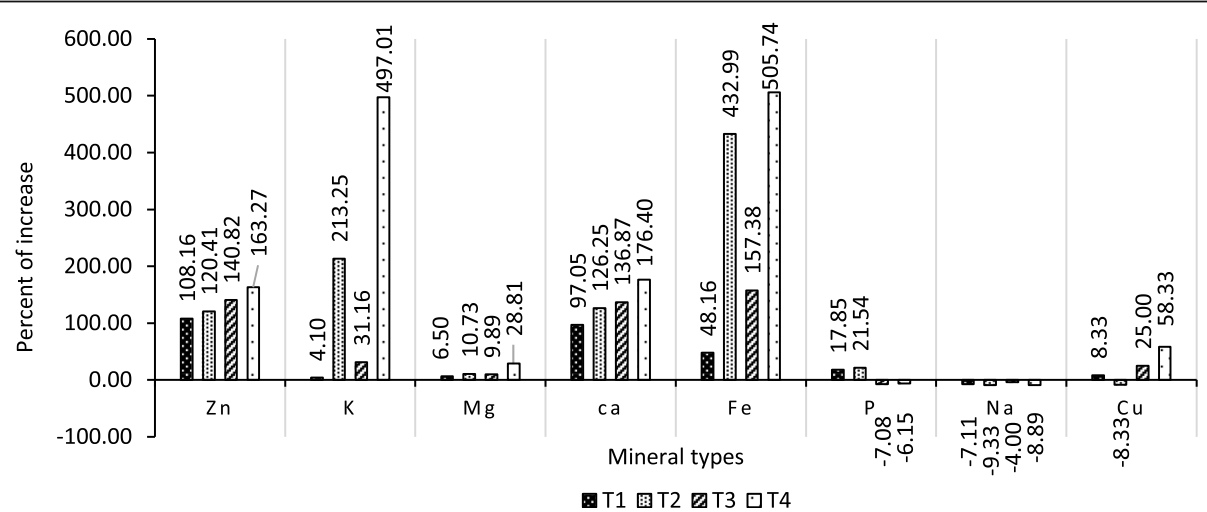

Fig. 2 Percent increase of minerals content in extruded snacks. T1, T2, T3 and T4: extruded corn products fortified with 3\% (w/w) of laurel, turmeric, ginger and mixture formula contains $3 \%$ of the three herbs' mixture mentioned (1:1:1), respectively 
Table 5 Vitamin estimation of raw blends and extruded products per $100 \mathrm{~g}$

\begin{tabular}{|c|c|c|c|c|}
\hline \multirow{2}{*}{$\begin{array}{l}\text { Parameters } \\
\text { Types }\end{array}$} & \multicolumn{2}{|c|}{ Vitamin B6 (mg) } & \multicolumn{2}{|l|}{ Vitamin A (IU) } \\
\hline & Raw blends & Extruded product & Raw blends & Extruded product \\
\hline $\bar{C}$ & $0.04 \pm 0.01^{c}$ & $0.03 \pm 0.00^{b}$ & $500 \pm 1.07^{d}$ & $310 \pm 1.45^{d}$ \\
\hline $\mathrm{T} 1$ & $0.091 \pm 0.02^{\mathrm{a}}$ & $0.02 \pm 0.00^{b}$ & $669.74 \pm 2.32^{c}$ & $316 \pm 2.01^{c}$ \\
\hline $\mathrm{T} 2$ & $0.093 \pm 0.00^{\mathrm{a}}$ & $0.08 \pm 0.02^{\mathrm{a}}$ & $3448.6 \pm 1.27^{\mathrm{a}}$ & $445 \pm 2.17^{\mathrm{a}}$ \\
\hline $\mathrm{T} 3$ & $0.044 \pm 0.00^{c}$ & $0.01 \pm 0.00^{c}$ & $485.87 \pm 1.25^{\mathrm{e}}$ & $283 \pm 2.07^{\mathrm{e}}$ \\
\hline T4 & $0.064 \pm 0.03^{b}$ & $0.05 \pm 0.01^{\mathrm{b}}$ & $1554.07 \pm 1.17^{\mathrm{b}}$ & $335 \pm 1.26^{\mathrm{b}}$ \\
\hline
\end{tabular}

Raw blends: blends prepared before extrusion process. Control: plain extruded product. T1, T2, T3 and T4: extruded corn product fortified with 3\% (w/w) of laurel, turmeric, ginger and mixture formula contains $3 \%$ of the three herbs' mixture mentioned (1:1:1), respectively

21 phenolic compounds in herbal snacks T1, T2, T3 and $\mathrm{T} 4$, respectively. In all extrudates, the maximum content was only found for ferulic acid and catechin. The retention percent was ranged from 219 to $78 \%, 351$ to $63.01 \%, 714$ to $44 \%, 255$ to $82.4 \%$ and from 294 to $59.92 \%$ in corn snacks, T1, T2,T3 and T4, respectively. The largest retention percent was found for cinnamic acid $(714 \%)$ and was detected in T2.

\section{Physical characteristics of extruded snacks blends}

The colour analysis presented in Table 8 showed values ranged from 74.5 to 91.93 for $\mathrm{L}^{*}$, and from 5.5 to -3.79 for $\mathrm{a}^{*}$, and from 27.66 to 43.02 for the $\mathrm{b}^{*}$ in all corn snacks. The highest $L^{*}$ value (91.93) was observed in control-corn snacks followed by T3 (80.99). The lowest $L^{*}$ value (74.5) was noted in T1. Regarding the redness degree, the highest $\mathrm{a}^{*}$ value (5.5) was obtained in control-corn snacks followed by T3 (2.5), while other treatments took the negative value indicating the greenish degree and the maximum negative $\mathrm{a}^{*}$ value were for T1 (-3.79). For $b^{*}$ value, the highest yellowish degree was apparent in T2, followed by T4, whereas the lowest $b^{*}$ value was noted with T3. Other treatments took a median yellowish value indicated by the low hue value (h). Higher values of $\Delta \mathrm{E}$ were obtained with $\mathrm{T} 2$ followed by $\mathrm{T} 1$. Whereas the colourfulness intensity, chroma $\left(\mathrm{C}^{*}\right)$ was the uppermost in T4 followed by T2.

As demonstrated in Table 8, supplementation of corn flour with dried herbs showed a significant impact on expansion ratio as well as piece density of the extruded corn snacks. T2 had the highest value for expansion ratio (4.02), while T3 had the lowest value (2.83). The extruded-corn snacks had a bulk density's value ranged from 0.35 to $0.12 \mathrm{~g} / \mathrm{cm}^{3}$. The maximum bulk density's value was for $\mathrm{T} 2$, whereas the lowest was for controlcorn snacks and T2. The largest open-cells emerged in

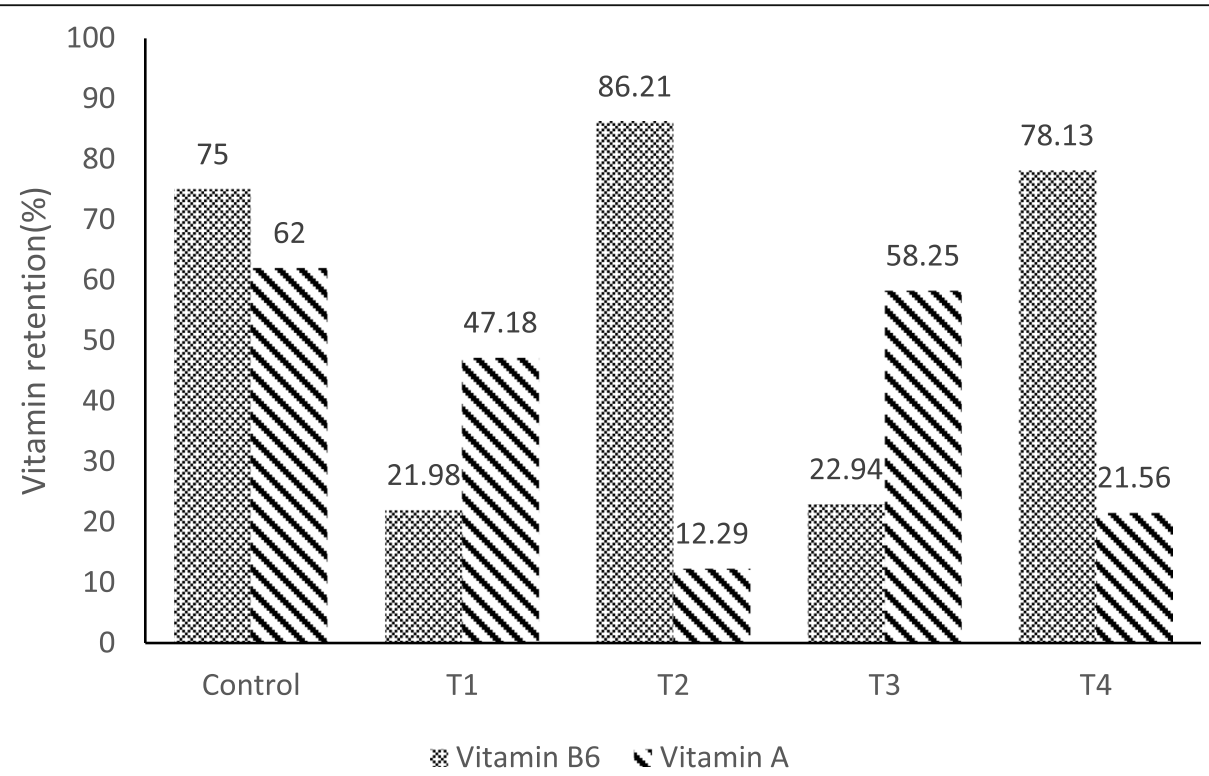

Fig. 3 The vitamin retention percent of extruded products as compared to raw blends. Control: plain extruded product. T1, T2, T3 and T4: extruded corn products fortified with $3 \%(\mathrm{w} / \mathrm{w})$ of laurel, turmeric, ginger and mixture formula contains $3 \%$ of the three herbs' mixture mentioned (1:1:1), respectively 
Table 6 Different functional properties of raw blends and extruded products

\begin{tabular}{|c|c|c|c|c|c|c|}
\hline \multirow{2}{*}{$\begin{array}{l}\text { Parameters } \\
\text { Types }\end{array}$} & \multicolumn{2}{|c|}{ TPC (mg/100 g) } & \multicolumn{2}{|l|}{ TFC $(\mathrm{mg} / 100 \mathrm{~g})$} & \multicolumn{2}{|l|}{ AOXA (\%) } \\
\hline & Raw blends & Extruded product & Raw blends & Extruded product & Raw blends & Extruded product \\
\hline C & $180.37 \pm 0.5^{d}$ & $21.63 \pm 0.75^{9}$ & $57.79 \pm 0.31^{h}$ & $76.6 \pm 0.45^{d}$ & $12.89 \pm 0.72^{e}$ & $15.59 \pm 0.38^{e}$ \\
\hline $\mathrm{T} 1$ & $214.55 \pm 0.5^{c}$ & $119.38 \pm 0.6^{d}$ & $205.75 \pm 0.86^{c}$ & $221.03 \pm 0.45^{a}$ & $76.01 \pm 0.15^{\mathrm{a}}$ & $64.44 \pm 0.66^{\mathrm{a}}$ \\
\hline $\mathrm{T} 2$ & $212.65 \pm 0.6^{c}$ & $182.32 \pm 0.5^{\mathrm{a}}$ & $282.31 \pm 0.03^{\mathrm{a}}$ & $141 \pm 0.01^{b}$ & $69.54 \pm 0.43^{b}$ & $50.09 \pm 0.25^{b}$ \\
\hline T3 & $246.98 \pm 0.7^{\mathrm{a}}$ & $125.92 \pm 0.5^{c}$ & $250.87 \pm 0.93^{b}$ & $90.10 \pm 0.34^{c}$ & $47.36 \pm 0.77^{d}$ & $30.98 \pm 0.83^{d}$ \\
\hline $\mathrm{T} 4$ & $224.72 \pm 0.92^{b}$ & $139.66 \pm 0.6^{b}$ & $246.31 \pm 0.61^{b}$ & $103.68 \pm 0.97^{c}$ & $61.97 \pm 0.12^{c}$ & $37.02 \pm 0.99^{c}$ \\
\hline
\end{tabular}

AoxA: total antioxidant activity; TPC: total phenolic content; TFC: total flavonoid content (mg/100 g). T1, T2, T3 and T4: extruded corn product fortified with 3\% (w/ w) of laurel, turmeric, ginger and mixture formula contains $3 \%$ of the three herbs' mixture mentioned (1:1:1), respectively

T2 with a reduced number as indicated by the crosssection view; nevertheless, the ginger snack (T3) showed many little air cells (Table 8, Fig. 5).

The rheology properties of extruded corn snacks are represented in Table 9. It was indicated that the texture analysis for snacks exhibited a hardness values ranged from 24.17 (T3) to $18.09 \mathrm{~N}$ (T1). Maximum adhesiveness (0.3) was recorded for the control sample and T4, while the lowest value was observed with $\mathrm{T} 1$ and $\mathrm{T} 2$. It was also noticed that springiness, gumminess and chewiness gave the highest value in T1 and the lowest value in T3. Regarding resilience, the maximum value was noted in the control-corn snacks, whereas the minimum value was observed in $\mathrm{T} 4$.

\section{Microbial analysis}

The microbial load of extruded-corn snacks during storing for 9 months at room temperature was very low to count. The findings indicate that both TBC and Y\&M were missing for 6 months. After 9 months of storage, fewer TBCs emerged in the control group alone (2.3 log $\mathrm{CFU} / \mathrm{g}$ ). Also, fewer yeasts and mold colonies started to appear in extruded samples but it was relatively higher in the control sample $(2.95 \log \mathrm{CFU} / \mathrm{g})$ than in the other herbal corn snacks (ranging from 1 to $1.3 \log \mathrm{CFU} / \mathrm{g}$ ). As well the coliform group was not detectable in all extruded products during storage periods. In T4 treatment, there was a complete absence of TBC and Y\&M during the period of storage.

\section{Discussion}

Extruded food products are accepted by the public of all ages. But these products have low functional value (Prabha et al. 2021). The present study consolidated extruded snacks of corn with various herbs including bay

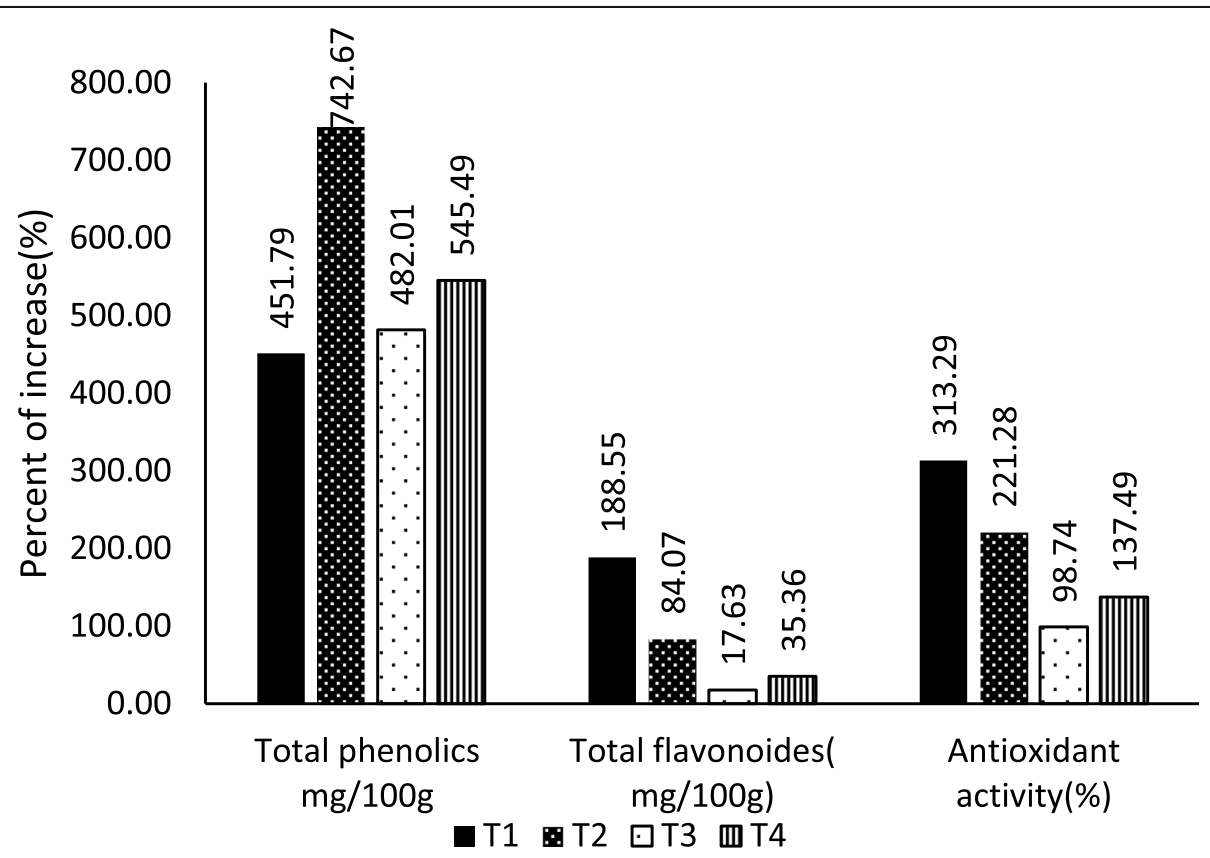

Fig. 4 The increasing percent of functional properties in treatments as compared to control. Control: plain extruded product. T1, T2, T3 and T4: extruded corn products fortified with 3\% (w/w) of Laurel, turmeric, ginger and mixture formula contains 3\% of mix of the three herbs used $(1: 1: 1)$, respectively 


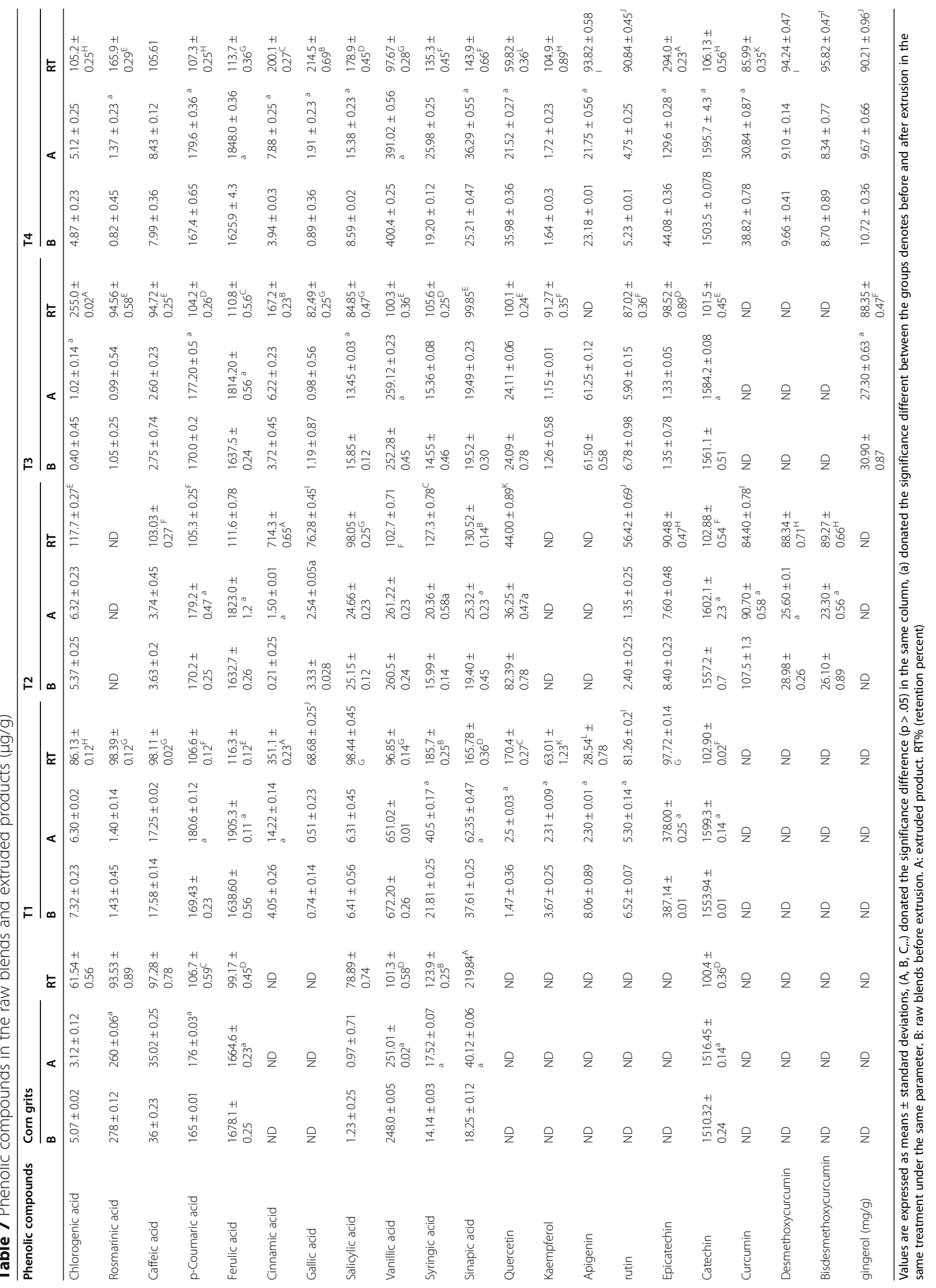


Table 8 Colour analysis, expansion ratio and bulk density and cross section analysis of extruded corn snacks

\begin{tabular}{|c|c|c|c|c|c|c|c|c|c|c|}
\hline \multirow[t]{2}{*}{ Treatments } & \multicolumn{6}{|c|}{ Colour parameters } & \multirow{2}{*}{$\begin{array}{l}\text { Expansion } \\
\text { ratio }\end{array}$} & \multirow{2}{*}{$\begin{array}{l}\text { Bulk density } \\
\left(\mathrm{g} / \mathrm{cm}^{3}\right)\end{array}$} & \multirow{2}{*}{$\begin{array}{l}\text { Mean area } \\
\text { of cells } \\
\left(\mathrm{mm}^{2}\right)\end{array}$} & \multirow{2}{*}{$\begin{array}{l}\text { Number } \\
\text { of cells }\end{array}$} \\
\hline & C & $\mathrm{L}^{*}$ & $a^{*}$ & $\mathbf{b}^{*}$ & $\mathrm{~h}$ & $E$ & & & & \\
\hline Control & $16.31 \pm 0.11^{d}$ & $91.93 \pm 0.52^{\mathrm{a}}$ & $5.5 \pm 0.12^{\mathrm{a}}$ & $30.1 \pm 0.23^{c}$ & $101.5 \pm 0.34^{\mathrm{a}}$ & $0 \pm 0.0$ & $3.33 \pm 0.01^{b}$ & $0.13 \pm 0.03^{d}$ & $0.361 \pm 0.4^{c}$ & 11 \\
\hline $\mathrm{T} 1$ & $16.12 \pm 0.22^{d}$ & $74.5 \pm 0.31^{\mathrm{e}}$ & $-3.79 \pm 0.22^{\mathrm{e}}$ & $30.96 \pm 0.86^{c}$ & $97.6 \pm 0.36^{d}$ & $20.56 \pm 0.33^{b}$ & $3.01 \pm 0.05^{c}$ & $0.26 \pm 0.02^{c}$ & $0.201 \pm 0.2^{c}$ & 14 \\
\hline $\mathrm{T} 2$ & $33.45 \pm 0.42 b$ & $76.73 \pm 0.44^{d}$ & $-1.15 \pm 0.01^{c}$ & $43.02 \pm 0.35^{\mathrm{a}}$ & $99.1 \pm 0.42^{c}$ & $25.33 \pm 0.45^{\mathrm{a}}$ & $4.02 \pm 0.03^{\mathrm{a}}$ & $0.12 \pm 0.01^{d}$ & $3.389 \pm 3.3^{\mathrm{a}}$ & 9 \\
\hline T3 & $17.06 \pm 0.32^{c}$ & $80.99 \pm 0.33^{b}$ & $2.23 \pm 0.22^{b}$ & $27.66 \pm 0.58^{d}$ & $94.8 \pm 0.22^{e}$ & $12.08 \pm 0.17^{d}$ & $2.83 \pm 0.07^{b}$ & $0.35 \pm 0.03^{b}$ & $0.212 \pm 0.3^{c}$ & 18 \\
\hline T4 & $36.35 \pm 0.32^{\mathrm{a}}$ & $77.8 \pm 0.21^{c}$ & $-2.34 \pm 0.11^{\mathrm{d}}$ & $35.37 \pm 0.23^{b}$ & $100.1 \pm 0.33^{b}$ & $17.79 \pm 0.55^{c}$ & $3.16 \pm 0.06^{d}$ & $0.16 \pm 0.04^{\mathrm{a}}$ & $1.255 \pm 1.9^{b}$ & 12 \\
\hline
\end{tabular}

$L^{*}:$ lightness; $a^{*}$ : red-green balance; $b^{*}$ : yellow-blue balance; $\Delta \mathrm{E}$ : total colour chance index, $h$ : Hue angle and $\Delta \mathrm{E}$ : Total colour difference, a-c: indicated with similar letters in columns do not differ significantly at $p=0.05$. T1, T2, T3 and T4: extruded corn product fortified with $3 \%(\mathrm{w} / \mathrm{w})$ of laurel, turmeric, ginger and mixture formula contains $3 \%$ of the three herbs' mixture mentioned (1:1:1), respectively

leaves, ginger, turmeric, and a mixture of them. These herbs were added by different ratios and the concentration of $3 \%$ of each treatment was selected according to the sensory properties defined by the judges. The inclusion of laurel leaves gave the highest score in flavour in snacks, which is linked to the richness of laurels with volatile oil. The principal volatile oils in bay leaves are 1,8-Cineole (31.9\%), sabinene (12.2\%), and linalool (10.2\%) (Caputo et al. 2017). The highest colour score was the turmeric-extruded snacks. Turmeric is considered a major source of polyphenol curcumin which gives it a spectacular yellow hue (Hewlings \& Kalman 2017). Whereas, ginger-extruded products have a pungency flavour, which develops primarily from its gingerol content, that when heated becomes dehydrated creating pungency compounds known as shogaols (Mao et al. 2019). On the other hand, the combined herbs-corn snacks (T4) have collected all the properties of the colour and taste of its herbal ingredients. It comes with a yellowgreen colour, rich taste with little pungency which can be preferred by children and young adults alike.

The nutritional value is considered the first concern in any commercial product. Moisture is a critical parameter in snack evaluation as it has contributed to the crispiness of the products (Yadav et al. 2018). The moisture levels of this study are close to those recorded by Goda et al. (2019). It has been found that ginger corn snacks represented the highest moisture content that was substantially different from other extruded types, which may be attributed to the water absorption potential of ginger as stated by Awad (2018). It was observed that all herbal extruded corn snacks had comparatively higher ash and fiber content with a lower content of carbohydrate compared to control. And these findings are consistent with Kaur et al. (2018) as they noticed the same results after using herbs like mint and basil. This relates to the alternation of starch content with other herbal ingredients such as fibers and minerals, which can be a promoting for weight loss.

Minerals have a vital role to play in human nutrition. The three spices used in developed extruded products; ginger, turmeric, and bay leaves have been established as important sources of various mineral elements such as potassium, magnesium, phosphorous, calcium, iron, and trace amounts of zinc (Guenane et al. 2016; NobileCorrea et al. 2020; Tanweer et al. 2014). Herbal corn snacks developed in the current study have shown that almost all types of minerals have risen after extrusion, with a marked increase in $\mathrm{Fe}, \mathrm{Ca}, \mathrm{K}$, and $\mathrm{Zn}$ content. This percent of the increase in mineral content was higher than what reported by Kaur et al. (2018) which was in the range of $19-29,38-77$ and $52-63 \%$ for total iron, calcium, and zinc content in the extruded product, respectively. Minerals are stable chemical elements. Although there is no clear explanation until now for the mineral behavior during extrusion, the reported increase in minerals after extrusions could be explained on the basis of degradation of phytate. Phytate is hydrolyzed and its phosphate molecule is released and inactivated, and this triggers the release of these elements (Alonso et al. 2001). Mineral elements are considered to be essential at all stages of human development. Calcium is required not just for bone formation throughout infancy and adolescence, but also for osteoporosis in postmenopausal women (Eastell et al. 2019; Levine 2012) the current manufactured herbal exrudated could provide a percent ranging from 29 to $35 \%$ of the daily required value (DV) for calcium recommended by FDA (2016). To the same extent, premenopausal women and small children are the most vulnerable to iron deficiency. Iron deficiency can impair behavior and learning ability (Allen, 2000). The herbal corn snacks contain 40.5-290 $\mathrm{mg} / \mathrm{g}$ of iron, which surpasses the recommended DV of $18 \mathrm{mg}$ (FDA 2016). Zinc has lately been advised to help combat the common cold, boost immunity, reduce diarrhea, and promote normal growth during pregnancy, infancy, and adolescence (Maret \& Sandstead 2006). The DV for zinc is $11 \mathrm{mg}$ (FDA 2016), thus the herbal corn snacks might supply a DV percent of around $90 \%$ per gram of snacks. Potassium is thought to have an important function in the control of skeletal muscle contraction, hypertension, reducing hypercalciuria and nerve impulse propagation (Stone et al. 2016). The current manufactured herbal corn extruded product could 


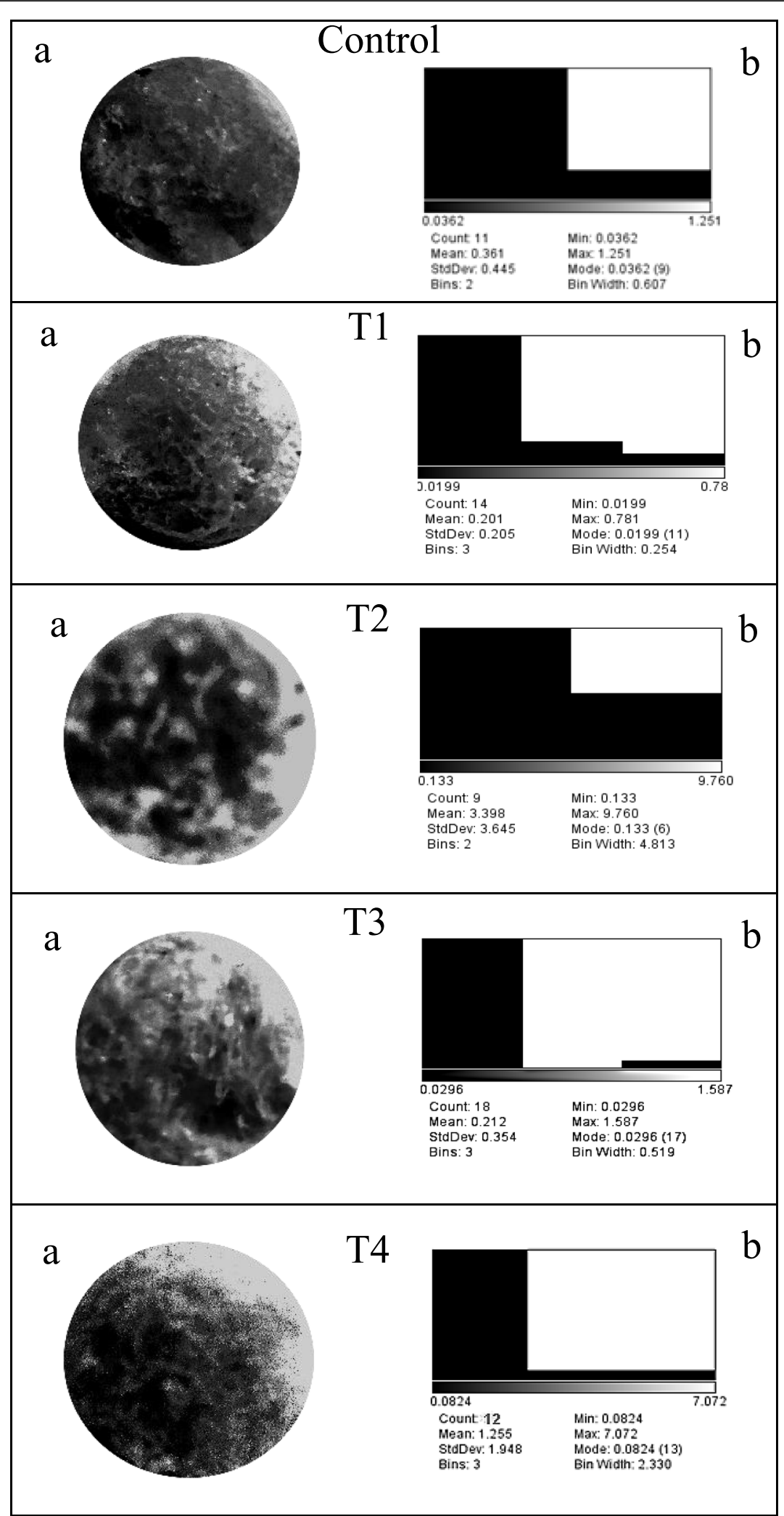

Fig. 5 The cross section analysis. (a): The cross section of the extruded product. (b): The area distribution of the cells. Control: plain extruded product. T1, T2, T3 and T4: extruded corn products fortified with $3 \%(\mathrm{w} / \mathrm{w})$ of laurel, turmeric, ginger and mixture formula contains $3 \%$ of mix of the three herbs used (1:1:1), respectively 
Table 9 Rheology properties of extruded snacks

\begin{tabular}{lllllll}
\hline Treatments & Hardness $\mathbf{( N )}$ & $\begin{array}{l}\text { Adhesiveness } \\
(\mathbf{m j})\end{array}$ & $\begin{array}{l}\text { Springiness } \\
(\mathbf{m m})\end{array}$ & $\begin{array}{l}\text { Gumminess } \\
(\mathbf{N})\end{array}$ & $\begin{array}{l}\text { Chewiness } \\
(\mathbf{m j})\end{array}$ & $\begin{array}{l}\text { Resilience } \\
\text { control }\end{array}$ \\
\hline $2.09 \pm 0.33^{\mathrm{c}}$ & $0.30 \pm 0.02^{\mathrm{a}}$ & $1.53 \pm 0.05^{\mathrm{c}}$ & $9.30 \pm 0.62^{\mathrm{b}}$ & $14.4 \pm 0.55^{\mathrm{b}}$ & $0.25 \pm 0.04^{\mathrm{a}}$ \\
T1 & $18.09 \pm 0.42^{\mathrm{d}}$ & $0.10 \pm 0.01^{\mathrm{e}}$ & $2.1 \pm 0.23^{\mathrm{b}}$ & $13.43 \pm 0.54^{\mathrm{a}}$ & $28.8 \pm 0.52^{\mathrm{a}}$ & $0.09 \pm 0.01^{\mathrm{c}}$ \\
T2 & $20.73 \pm 0.53^{\mathrm{c}}$ & $0.20 \pm 0.04^{\mathrm{b}}$ & $0.75 \pm 0.11^{\mathrm{a}}$ & $6.0 \pm 0.33^{\mathrm{c}}$ & $4.5 \pm 0.71^{\mathrm{c}}$ & $0.19 \pm 0.06^{\mathrm{c}}$ \\
T3 & $24.17 \pm 0.43^{\mathrm{a}}$ & $0.40 \pm 0.08^{\mathrm{a}}$ & $-0.06 \pm 0.04^{\mathrm{e}}$ & $0.02 \pm 0.0^{0 \mathrm{e}}$ & $-0.2 \pm 0.05^{\mathrm{e}}$ & $0.1 \pm 0.05^{\mathrm{b}}$ \\
T4 & $22.81 \pm 0.21^{\mathrm{b}}$ & $0.30 \pm 0.03^{\mathrm{a}}$ & $0.00 \pm 0.00^{\mathrm{d}}$ & $1.9 \pm 0.41^{\mathrm{d}}$ & $0.0 \pm 0.00^{\mathrm{d}}$ & $0.06 \pm 0.02^{\mathrm{d}}$ \\
\hline
\end{tabular}

$\mathrm{T} 1, \mathrm{~T} 2, \mathrm{~T} 3$ and T4: extruded corn product fortified with $3 \%(\mathrm{wt} / \mathrm{wt}$ ) of laurel, turmeric, ginger and mixture formula contains $3 \%$ of the three herbs' mixture mentioned (1:1:1), respectively

supply a DV \% of potassium ranging from 11.7 to $68 \%$ (FDA 2016). According to the FDA, foods that provide $20 \%$ or more of the DV are considered rich sources of a nutrient, although items that provide lower percentages of the DV also contribute to a healthy diet.

Vitamins are also known to be an integral part of the diet (Godswill et al. 2020). Vitamin B6 is among watersoluble vitamins, is considered as an enzymatic co-factor that is integrated into numerous biochemical reactions such as biosynthetic pathway of amino acids, and metabolic process of sugar, and fatty acid (Ball 2006). Vitamin B6 has been found to be also a potent antioxidant (Sorolla et al. 2010). Scientific investigations have shown that DNA damage caused by micronutrient deficiencies, such as vitamin B6, may lead to stunted growth, anemia, poor immune function, and cancer (Liu et al. 2008; Qian et al. 2017). B6 is regarded as the most heat-sensitive (Killeit 1994). Although some researchers reported stability of B6 during extrusion, others reported a loss (Yang et al. 2020). In the current results, the vitamin retention percent for B6 was ranged from 21 to $78 \%$. It seems that this effect depends not only on the production process but also on the food mixtures used. These findings are consistent with a variety of authors. For instance, Athar et al. (2006) recorded a vitamin B6 retention percent of 18 and 35\% for the corn-peas mixture and the extruded oat flour, respectively.

Vitamin A is essential for proper immune functions and the deficiency of this vitamin is the leading cause of blindness in many developing countries. Vitamin A and related carotenoids are not stable in the presence of oxygen and heat and are thus particularly vulnerable during extrusion. Because vitamin A contains four double bonds and one hydroxyl group, which are unstable at high temperatures (Athar et al. 2006; Kostadinović et al. 2014). Vitamin A content in turmeric rhizome powder was reported to be $3.44 \mathrm{mg} / \mathrm{g}$ (Imoru et al. 2018). The prepared herbal extrudates could cover a DV\% ranged from 14 to $9.4 \%$ of the daily value of vitamin A recommended by FDA (2016). Although the turmeric-raw blends showed the highest content in vitamin A, they displayed the lowest percent retention after extrusion. The retention of vitamins in cereal during the extrusion process is not apparently linked to the original levels of the vitamins (Athar et al. 2006). Yang et al. (2020) rated vitamin stability during extrusion and stated that vitamin B6 was relatively stable, while vitamin A was very sensitive.

Because of their known antioxidant characteristics, the phytochemicals in cereals attract considerable scrutiny owing to their worthy impact on human health (Horvat et al. 2020). In L. nobilis extracts, the total phenols and flavonoids were previously stated to be $25.70 \pm 0.86 \mathrm{mg}$ $\mathrm{GAE} / \mathrm{g}$ and $12.11 \pm 0.43 \mathrm{mg} \mathrm{CE} / \mathrm{g}$, respectively (Guenane et al. 2016). In the case of ginger, it was informed to be $52.8 \mu \mathrm{g} \mathrm{GAE} / \mathrm{mg}$ and $3.9 \mu \mathrm{g} \mathrm{QE} / \mathrm{mg}$, respectively (Tohma et al. 2017). Whereas it ranged from 3.8 to $221 \mathrm{mg} \mathrm{GAE} /$ $\mathrm{g}$ and 0.6 to $549.2 \mathrm{mg} \mathrm{QE} / \mathrm{g}$ for turmeric extracts, respectively. It is already established that the antioxidant properties of phenolic compounds depends on the ability to scavenge free radicals, to give hydrogen atoms, electrons, or chelate metal cations (Afanas'ev et al. 1989). In the extrusion process, heat introduces two different effects on phenolic molecules, the first being the increase in the phenolic levels caused by the liberation of these substances out of the cell membrane/wall under the influence of heat (Dewanto et al. 2002). While the other effect is the modification or the destruction of the chemical structure of these compounds that will eventually lead to a reduction in their quantity and activity, due to the exposure to high heat and time of exposure during the extrusion process (Vega-Gálvez et al. 2012). That reduction is not often correlated with the same proportion of the decline in the antioxidant capacity as the Millard reaction could accumulate other antioxidant molecules that would decrease such loss (Vega-Gálvez et al. 2012). Decreased functional parameters have also been documented in other extruded items that differ by food type (Limsangouan et al. 2010) and a reduction of $80 \%$ of phenolic content has been reported (Repo-Carrasco-Valencia et al. 2009). Also, the results showed a strong positive correlation between antioxidant activity and total flavonoids $(r=0.94)$, but its relationship with polyphenolic content was moderately high $(r=0.65)$. A lack of correlation $(r=0.20)$ between TPC and DPPH was indicated to occur in corn samples (Horvat et al. 2020). 
The utilization of herbs in this study may be the explanation for the moderate relationship appearance.

In the current study, the extrusion cooking did not introduce an alteration in phenolic profiles but only change its concentration. The predominance of ferulic acid and catechin in all extrudates is related to the richness of yellow corn of these compounds. Herein, introducing herbs to corn increases the phenolic compounds in extrudates. This is obviously noticed by the detection of gingerol and curcumin in ginger and turmeric snacks. Besides including both of these compounds in herbalmixture snacks. Gingerol is known for its antioxidant, anti-tumor and anti-inflammatory properties. Also it can reverse or prevent chronic diseases (Aryaeian \& Tavakkoli 2015). Many studies have publicised the health benefits of curcumin, demethoxycurcumin and bisdemethoxycurcumin, which are main active compound in turmeric such as anti-bacterial, anti-viral, anti-oxidant, anti-inflammatory and anticancer activities (Jayathilake et al. 2021; Rathore et al. 2020).

The first physical characteristic that draws customers is color (Turner 1995). The incorporation of diverse herbs expressly led to a distinct coloration in the achieved study. The presence of carotenoid in corn flour gives the control-corn snacks a light yellow color (Kannadhason \& Muthukumarappan 2010, Shah et al. 2017). The most noticeable color shift was that of turmeric, which displayed a golden color that naturally resulted from its curcumin concentration (Nobile-Correa et al. 2020). In addition, bay laurel has a more greenish color due to its chlorophyll concentration (Ayanoğlu et al. 2018). Lightness $L$ reduced somewhat after herbal addition, and the similar tendency was reported in fruit-corn snakes by Wójtowicz et al. (2020). The total color difference, on the other hand, defines the amount of color difference between treated and control samples (Mokrzycki \& Tatol 2012). The greatest difference was observed with turmeric snacks. Furthermore, chroma $\left(C^{*}\right)$ is regarded as a quantitative feature of colorfulness, and according to the results, turmeric and a mixture of herbs-snacks exerted the highest color intensity. Since the hue angle $\left(\mathrm{h}^{*}\right)$ represented the qualitative quality of color, a lower hue angle indicates a more yellow character. The hue angle range achieved is similar to that found with spirulina-extruded snacks, which are reported to have a green hue ranging from 85 to 92 (Lucas et al. 2017). Different processes, such as the Millard reaction, caramelization, hydrolysis, and pigment degradation, may also have an effect on the degree of color (Kannadhason \& Muthukumarappan 2010).

The expansion ratio is an important parameter in the extruded product. The expansion ratio depends on different factors like initial moisture, type of fibers, and protein contents (Minweyelet et al. 2021). Herein the ginger snacks showed less expansion ratio, which may be related to the higher moisture content. The plasticizing effect of the water makes a reduction in starch viscosity that restricts the bubble growth so producing many small air cells with low surface area (Ding et al. 2005) and that like what observed in cross section of ginger snacks. On the same trend, the presence of high fiber and protein content will results in a further harder, less expanded and denser extruded product (Chou \& Hsu, 2020) and that comparable with what observed in laurel and ginger snacks. Oppositely, the addition of turmeric in corn snacks led to a more expanded product than other extruded products and with a density value closer to control. Turmeric powder has starch in its composition, distinguished by its smooth surface (Tejavathi et al. 2020). This turmeric-starch has described as having a high range of gelatinization and viscosity (Santana et al. 2017), which would lead to further swelling of the dough allowing for an extra expanded softer surface which is also noted in cross section giving the largest cell area. The obtained range of bulk density is closely similar to that found by Ding et al. (2005) which was between 0.10 and $0.43 \mathrm{~g} / \mathrm{cm}^{3}$ for extruded rice-based snacks. As well shah et al. (Shah et al. 2017) reported values ranged from 2.64 to 5.72 and from $0.34-0.44 \mathrm{~g} / \mathrm{cm} 3$ for expansion ratio and the piece density, respectively.

Texture parameters are known to be major challenge faced by extruded puff products. Hardness refers to the peak force. A product with a lower density, lesser hardness and a highly porous structure is preferred for crispy extrudates (Saeleaw et al. 2012). There was no big difference in the hardness values of the current products. Nevertheless, the ginger snacks score a superior hardness value compared to other extrudates. That may be related to the higher water content in ginger snacks which will also result in a decrease in the expanding level (Petrova et al. 2010). Adhesiveness is the tendency of the food to stick to the teeth as it is chewed. This property is known for the buffed products (Liu et al. 2000). Researchers have reported that the stickiness of the product is similarly increased with high moisture content (Shruthi et al. 2019) that is clearly noticed with ginger snacks in the obtained findings. In crispy products, the ability to spring back is less and that is evident in the current results in the herbal-mixture snacks. Likewise, resilience explains how much a product can struggle for recovery but if the product is crispy it will get break and show less resilience (Leonard et al. 2020). Approximately all treatments showed a lower value of resilience in comparison to control. Springiness in the current results is positively linked to gumminess $(r=$ $0.99)$ and chewiness $(r=0.96)$. Also, gumminess is strongly correlated with chewiness $(r=0.95)$. These parameters are related with each other as they describe 
how the product behaves during bites. However, hardness gave a clear downhill relationship with gumminess, springiness and chewiness $(\mathrm{r}=-0.98,-0.96$ and -0.91 respectively) which have similarities with the findings of Liu et al. (Liu et al. 2000) and Shah et al. (Shah et al. 2017).

Microbiological load indicated the quality of handling and storage circumstances; all extruded products were determined to be within permissible limits during storage at room temperature for 6 months for the control sample and 9 months for the herbal extruded products (ICMSF 2011). Because the high temperature utilized during extrusion is high enough to eradicate microbiological dangers, which may be comparable to the sterilizing procedure (Syed et al. 2019; Wani et al. 2020). The lack of yeast and molds during storage is familiar with the finding of (Morsy et al. 2014). Furthermore, the coliform group was missing from all analysed samples, which was similar with the findings of other authors (Syed et al. 2019, Wani et al. 2020). However, the current complete lack of total bacterial counted over 9 months for herbal extruded snacks outperforms the findings of other authors who reported lower total counts of bacteria, yeast, and molds (Raja et al. 2014; Vijayarani et al. 2012). And that could be associated with the antimicrobial activity exhibited by the currently used herbs. Since, polyphenols of bay leaves, ginger, and turmeric were confirmed to have potent antimicrobial activity (Joe et al. 2004; Dadalioglu \& Evrendilek 2004, Beristain-Bauza et al. 2019)

\section{Conclusions}

The production of healthier foods is presently the main focus of the industrial process. The most obvious conclusion from this study is that two extruded products which is turmeric and herbal mixture snacks with the highest mineral content, including potassium, calcium, zinc, and iron, as well as the highest levels of vitamin B6 and A, may be regarded a rich nutritious diet. It also had a higher phytochemical content and better rheological qualities than the standard product. Furthermore, the extended shelf life of these herbal corn snacks assures that the product is microbiologically safe. Thus, including the aforementioned dry herbs into extruded maize snacks could make a significant contribution to the field of functional food.

\section{Abbreviations}

HTST: High- Temperature and Short-term Technology; WHO: World Health Organization; AACC: The American Association of Cereal Chemists; HPLC: High Performance Liquid Chromatography; DPPH: 2,2-Diphenyl-1picrylhydrazyl; TFC: Total flavonoids content; TPC: Total polyphenols content; AOXA: Antioxidant activity of extruded products; ER: Expansion ratio; BD: Bulk density; APHA: American Public Health Association; TBC: Total Bacterial Count; YM: Yeast and Mould counts

\section{Acknowledgements}

No Acknowledgments to declare

\section{Authors' contributions}

SAA, designed the study. SAA and AER carried out the experiment. SAA interpreted the results and drafted the manuscript. SAA and AER reviewed the manuscript. The authors read and approved the final manuscript.

\section{Funding}

'Not applicable'

Availability of data and materials

Authors declare that all generated and analysed data are included in the article.

\section{Declarations}

Ethics approval and consent to participate

Not applicable

\section{Consent for publication}

Not applicable

\section{Competing interests}

The authors declare that they have no conflict of interest

Received: 21 November 2021 Accepted: 3 January 2022

Published online: 07 February 2022

\section{References}

AACC (2000). Approved methods of American Association of Cereal Chemists, (10th ed., ). St. Paul, MN: The American Association of Cereal Chemists, Inc.

Afanas'ev, I. B., Dcrozhko, A. I., Brodskii, A. V., Kostyuk, V. A., \& Potapovitch, A. I. (1989). Chelating and free radical scavenging mechanisms of inhibitory action of rutin and quercetin in lipid peroxidation. Biochemical Pharmacology, 38(11), 1763-1769. https://doi.org/10.1016/0006-2952(89)90410-3.

Alam, S. A., Järvinen, J., Kirjoranta, S., Jouppila, K., Poutanen, K., \& Sozer, N. (2014). Influence of particle size reduction on structural and mechanical properties of extruded rye bran. Food and Bioprocess Technology, 7(7), 2121-2133. https://doi.org/10.1007/s11947-013-1225-2.

Allen, L. H. (2000). Anemia and iron deficiency: effects on pregnancy outcome. The American Journal of Clinical Nutrition, 71(5 Suppl), 1280S-4S. https://doi. org/10.1093/ajcn/71.5.1280s.

Alonso, R., Rubio, L. A., Muzquiz, M., \& Marzo, F. (2001). The effect of extrusion cooking on mineral bioavailability in pea and kidney bean seed meals. Animal Feed Science and Technology, 94(1-2), 1-13. https://doi.org/10.1016/ s0377-8401(01)00302-9

Alvarez-Martinez, L., Kondury, K. P., \& Harper, J. M. (1988). A general model for expansion of extruded products. Journal of Food Science, 53(2), 609-615. https://doi.org/10.1111/j.1365-2621.1988.tb07768.x.

AOAC (2005). Association of Official Analytical Chemist, Official Methods of Analysis. 18th Edition, AOAC International, Suite 500, 481 North Frederick Avenue, Gaithersburg, Maryland 20877-2417, USA.

Aryaeian, N., \& Tavakkoli, H. (2015). Ginger and its effects on inflammatory diseases. Advances in Food Technology and Nutritional Sciences, 1(4), 97-101. https://doi.org/10.17140/AFTNSOJ-1-11.

Athar, N., Hardacre, A., Taylor, G., Clark, S., Harding, R., \& McLaughlin, J. (2006). Vitamin retention in extruded food products. Journal of Food Composition and Analysis: An Official Publication of the United Nations University, International Network of Food Data Systems, 19(4), 379-383. https://doi.org/1 0.1016/j.jfca.2005.03.004.

Awad, S. M. S. (2018). Utilization of ginger powder (Zingiber officinale roscoe) in functional food production. Australian Journal of Basic and Applied Sciences, 12(12), 121-130. https://doi.org/10.22587/ajbas.2018.12.12.20.

Ayanoğlu, F., Kaya, D. A., \& Bahadirli, N. P. (2018). Effects of planting density and harvesting time on leaf and essential oil yield of bay Laurel (Laurus nobilis L.) cultured in shrub form. International conference on advanced materials and systems (ICAMS).289-249. https://doi.org/10.24264/icams-2 018.VI.1

Ball, G. M. F. (2006). Vitamins in foods. In Analysis, bioavailability and stability. Boca Raton: CRC, Press. https://doi.org/10.1201/9781420026979. 
Bergström, L. (1998). Nutrient losses and gains in the preparation of food. National Food Administration, Sweden: Livsmedelsverket.

Beristain-Bauza, S. D. C., Hernández-Carranza, P., Cid-Pérez, T. S., Ávila-Sosa, R., Ruiz-López, I. I., \& Ochoa-Velasco, C. E. (2019). Antimicrobial activity of ginger (Zingiber officinale) and its application in food products. Food Reviews International, 35(5), 407-426. https://doi.org/10.1080/87559129.2019.1573829.

Bitsch, R., \& Möller, J. (1989). Analysis of B6 vitamers in foods using a modified high-performance liquid chromatographic method. Journal of Chromatography, 463(1), 207-211. https://doi.org/10.1016/s0021-9673 (01)84472-1

Caputo, L., Nazzaro, F., Souza, L. F., Aliberti, L., De Martino, L., Fratianni, F., ... De Feo, V. (2017). Laurus nobilis: Composition of essential oil and its biological activities. Molecules (Basel, Switzerland), 22(6). https://doi.org/10.3390/ molecules22060930.

Chin Fu, Chou Shu Chen, Hsu (2021) Effects of extrusion parameters on the physicochemical characteristics of extruded barley ready-to-eat snacks. Journal of Food Processing and Preservation 45(10) https://doi.org/10.1111/ jfpp.15788.

Dadalioglu, I., \& Evrendilek, G. A. (2004). Chemical compositions and antibacterial effects of essential oils of Turkish oregano (Origanum minutiflorum), bay laurel (Laurus nobilis), Spanish lavender (Lavandula stoechas L.), and fennel (Foeniculum vulgare) on common foodborne pathogens. Journal of Agricultural and Food Chemistry, 52(26), 8255-8260. https://doi.org/10.1021/ jfo49033e.

Dennison, D. B., \& Kirk, J. R. (1977). Quantitative analysis of vitamin a in cereal products by high speed liquid chromatography. Journal of Food Science, 42(5), 1376-1379. https://doi.org/10.1111/j.1365-2621.1977.tb14502.x.

Dewanto, V., Wu, X., \& Liu, R. H. (2002). Processed sweet corn has higher antioxidant activity. Journal of Agricultural and Food Chemistry, 50(17), 49594964. https://doi.org/10.1021/jf0255937.

Ding, Q.-B., Ainsworth, P., Tucker, G., \& Marson, H. (2005). The effect of extrusion conditions on the physicochemical properties and sensory characteristics of rice-based expanded snacks. Journal of Food Engineering, 66(3), 283-289. https://doi.org/10.1016/j.jfoodeng.2004.03.019.

Eastell, R., Rosen, C. J., Black, D. M., Cheung, A. M., Murad, M. H., \& Shoback, D. (2019). Pharmacological management of osteoporosis in postmenopausal women: An endocrine society* clinical practice guideline. The Journal of Clinical Endocrinology and Metabolism, 104(5), 1595-1622. https://doi.org/1 0.1210/jc.2019-00221

FDA (2016). U.S. Food and Drug Administration. Food Labeling: Revision of the Nutrition and Supplement Facts Labels. 2016.

Goda, S., Galal, G., \& El-Shourbagy, G. (2019). Fortification of extruded snacks using some fruit peels. Zagazig Journal of Agricultural Research, 46(5), 15391551. https://doi.org/10.21608/zjar.2019.48171.

Godswill, A. G., Somtochukwu, I. V., Ikechukwu, A. O., \& Kate, E. C. (2020). Health benefits of micronutrients (vitamins and minerals) and their associated deficiency diseases: A systematic review. International Journal of Food Sciences, 3(1), 1-32. https://doi.org/10.47604/ijf.1024.

Grasso, S. (2020). Extruded snacks from industrial by-products: A review. Trends in Food Science \& Technology, 99, 284-294. https://doi.org/10.1016/j.tifs.2020.03.012.

Guenane, H., Gherib, A., Carbonell-Barrachina, Á., Cano-Lamadrid, M., Krika, F., Berrabah, M., ... Bakchiche, B. (2016). Minerals analysis, antioxidant and chemical composition of extracts of Laurus nobilis from southern Algeria. Journal of Materials and Environmental Science, 7(11), 42534261.

Hewlings, S. J., \& Kalman, D. S. (2017). Curcumin: A review of its effects on human health. Foods (Basel, Switzerland), 6(10). https://doi.org/10.3390/foods6100092.

Horvat, D., Šimić, G., Drezner, G., Lalić, A., Ledenčan, T., Tucak, M., ... Zdunić, Z. (2020). Phenolic acid profiles and antioxidant activity of major cereal crops. Antioxidants (Basel, Switzerland), 9(6), 527. https://doi.org/10.3390/a ntiox9060527.

ICMSF (2011). International commission on microbiological specification for foods. USDA information office. Microorganisms in Foods 8: Use of Data for Assessing Process Control and Product Acceptance. New York: Springer. https://doi.org/10.1007/978-1-4419-9374-8_1

Imoru, A., Onibi, G. E., \& Osho, I. B. (2018). Nutritional and biochemical compositions of turmeric (Curcuma longa Linn) rhizome powder - A promising animal feed additive. International Journal of Scientific \& Engineering Research, 9(1), 424-429.

Jayathilake, P. A. L., Jayasinghe, M., Walpita, J., \& Dilani, K. P. R. I. (2021). Turmeric and ginger as health protective food sources - an integrative review.
Vidyodaya Journal of Science., 24(02), 7-26. https://doi.org/10.31357/vjs.v24i02. 5405.

Joe, B., Vijaykumar, M., \& Lokesh, B. R. (2004). Biological properties of curcumincellular and molecular mechanisms of action. Critical Reviews in Food Science and Nutrition, 44(2), 97-111. https://doi.org/10.1080/10408690490424702.

Kannadhason, S., \& Muthukumarappan, K. (2010). Effect of starch sources on properties of Extrudates containing DDGS. International Journal of Food Properties, 13(5), 1012-1034. https://doi.org/10.1080/10942910902937416.

Karuppiah, P., \& Rajaram, S. (2012). Antibacterial effect of Allium sativum cloves and Zingiber officinale rhizomes against multiple-drug resistant clinical pathogens. Asian Pacific Journal of Tropical Biomedicine, 2(8), 597-601. https:// doi.org/10.1016/S2221-1691(12)60104-X

Kaur, G., Singla, N., Singh, B., \& Javed, M. (2018). Nutritional evaluation of cerealpulse based extruded snacks supplemented with dehydrated herbs. Current Journal of Applied Science and Technology, 28(1), 1-14. https://doi.org/10. 9734/CJAST/2018/41901.

Killeit, U. (1994). Vitamin retention in extrusion cooking. Food Chemistry, 49(2), 149-155. https://doi.org/10.1016/0308-8146(94)90151-1.

Kostadinović, L., Teodosin, S., Levi'c, J., Colovi'c, R., Banjac, V., Vukmirović, Đ., \& Sredanović, S. (2014). Effect of pelleting and expanding processes on vitamin A stability in animal feeds. Journal on Processing and Energy in Agriculture, 18, 44-46.

Lawless, H. T., \& Heymann, H. (2010). Sensory evaluation of food. In Principles and practices, (2nd ed., pp. 326-329). New York: Springer. https://doi.org/10.1007/ 978-1-4419-6488-5.

Leonard, W., Zhang, P., Ying, D., \& Fang, Z. (2020). Application of extrusion technology in plant food processing byproducts: An overview. Comprehensive Reviews in Food Science and Food Safety, 19(1), 218-246. https://doi.org/10.1111/1541-4337.12514.

Levine, M. A. (2012). Assessing bone health in children and adolescents. Indian Journal of Endocrinology and Metabolism, 16(Suppl 2), S205-S212. https://doi. org/10.4103/2230-8210.104040.

Limsangouan, N., Takenaka, M., Sotome, I., Nanayama, K., Charunuch, C., \& Isobe, S. (2010). Functional properties of cereal and legume based extruded snack foods fortified with by-products from herbs and vegetables. Kasetsart Journal - Natural Science, 44, 271-279.

Liu, S. Q., Cao, M. L., \& Dong, S. L. (2008). Electrochemical and ultraviolet-visible spectroscopic studies on the interaction of deoxyribonucleic acid with vitamin B6. Bioelectrochemistry, 74(1), 164-169. https://doi.org/10.1016/j. bioelechem.2008.07.004.

Liu, Y., Hsieh, F., Heymann, H., \& Huff, H. E. (2000). Effect of process conditions on the physical and sensory properties of extruded oat-corn puff. Journal of Food Science, 65(7), 1253-1259. https://doi.org/10.1111/j.1365-2621.2000.tb102 74.x.

Lotfi Shirazi, S., Koocheki, A., Milani, E., \& Mohebbi, M. (2020). Production of high fiber ready-to-eat expanded snack from barley flour and carrot pomace using extrusion cooking technology. Journal of Food Science and Technology, 57(6), 2169-2181. https://doi.org/10.1007/s13197-020-04252-5.

Lucas, B. F., de Morais, M. G., Santos, T. D., \& Costa, J. A. V. (2017). Effect of Spirulina addition on the physicochemical and structural properties of extruded snacks. Food Science And Technology, 37(spe), 16-23. https://doi. org/10.1590/1678-457x.06217.

Mao, Q.-Q., Xu, X.-Y, Cao, S.-Y., Gan, R.-Y., Corke, H., Beta, T., \& Li, H.-B. (2019). Bioactive compounds and bioactivities of ginger (Zingiber officinale roscoe). Foods (Basel, Switzerland), 8(6), 185. https://doi.org/10.3390/foods8060185.

Marchev, A., Georgiev, V., Ivanov, I., Badjakov, I., \& Pavlov, A. (2011). Two-phase temporary immersion system for agrobacterium rhizogenes genetic transformation of sage (Salvia tomentosa mill.). Biotechnology Letters, 33(9), 1873-1878. https://doi.org/10.1007/s10529-011-0625-5.

Maret, W., \& Sandstead, H. H. (2006). Zinc requirements and the risks and benefits of zinc supplementation. Journal of Trace Elements in Medicine and Biology, 20(1), 3-18. https://doi.org/10.1016/j.jtemb.2006.01.006.

Mazumder, P., Roopa, B. S., \& Bhattacharya, S. (2007). Textural attributes of a model snack food at different moisture contents. Journal of Food Engineering, 79(2), 511-516. https://doi.org/10.1016/j.jfoodeng.2006.02.011.

Minweyelet, M., Solomon, W. K., \& Bultosa, G. (2021). Effects of extrusion operating conditions and blend proportion on the physicochemical and sensory properties of teff-rice blend extruded products. Food Research, 5(2) 173-183. https://doi.org/10.26656/fr.2017.5(2).467.

Mohammed, R. R., Omer, A. K., Yener, Z., Uyar, A., \& Ahmed, A. K. (2021). Biomedical effects of Laurus nobilis $L$. leaf extract on vital organs in 
streptozotocin-induced diabetic rats: Experimental research. Annals of Medicine and Surgery, 61, 188-197. https://doi.org/10.1016/j.amsu.2020.11.051.

Mokrzycki, W. S., \& Tatol, M. (2012). Color difference Delta E-A survey. Machine Graphics and Vision, 20, 383-411.

Morsy, O. M., Sharoba, A. M., \& El-Desouky, A.l., Bahlol, H.E.M., \& Abd El Mawla, E., M. (2014). Production and evaluation of some extruded food products using spirulina algae. Annals of Agriculture Science, Moshtohor, 52(4), 495-510. https://doi.org/10.21608/assjm.2014.111899.

Nobile-Correa, D. P., Restrepo-Osorio, J., Zúñiga, O., \& Sánchez-Andica, R. A. (2020). Determination of nutritional value of turmeric flour and the antioxidant activity of Curcuma longa rhizome extracts from agroecological and conventional crops of Valle del Cauca-Colombia. Revista Colombiana de Química, 49(1), 26-32. https://doi.org/10.15446/rev. colomb.quim.v1n49.79334.

Onwuka, G. J. (2005). Food Analysis and instrumentation theory and practice, (pp. 64-76). Lagos, Nigeria: Naphthali Prints.

Petrova, T., Ruskova, M., Tzonev, P., Zsivanovits, G., \& Penov, N. (2010). AlP Conference Proceedings, 1203, 1031. https://doi.org/10.1063/1.3322303.

Prabha, K., Ghosh, P., Abdullah, S., Joseph, R. M., Krishnan, R., Rana, S. S., \& Pradhan, R. C. (2021). Recent development, challenges, and prospects of extrusion technology. Future Foods, 3, 100019. https://doi.org/10.1016/ffufo.2021.100019.

Qian, B., Shen, S., Zhang, J., \& Jing, P. (2017). Effects of vitamin B6 deficiency on the composition and functional potential of T cell populations. Journal of Immunology Research, 2017, 2197975. https://doi.org/10.1155/2017/2197975.

Raduly, F. M., Raditoiu, V., Raditoiu, A., \& Purcar, V. (2021). Curcumin: Modern applications for a versatile additive. Coatings, 11(5), 519. https://doi.org/10.33 90/coatings 11050519

Raja, W. H., Kumar, S., Bhat, Z. F., \& Kumar, P. (2014). Effect of ambient storage on the quality characteristics of aerobically packaged fish curls incorporated with different flours. Springer Plus, 3(1), 106-115. https://doi.org/10.1186/21 93-1801-3-106

Rathore, S., Siddiqui, M., Sharma, P., Devi, S., Nagar, J., \& Khalid, M. (2020). Curcumin: A review for health benefits. International Journal of Science and Research (IJSR), 7, 273-290.

Reitzer-Bergaentzle, M., Marchioni, E., \& Hasselmann, C. (1993). HPLC determination of vitamin B6 in foods after pre-column derivatization of free and phosphorylated vitamers into pyridoxol. Food Chemistry, 48(3), 321-324. https://doi.org/10.1016/0308-8146(93)90149-A.

Repo-Carrasco-Valencia, R., Acevedo de La Cruz, A., Icochea Alvarez, J. C., \& Kallio, H. (2009). Chemical and functional characterization of Kañiwa (Chenopodium pallidicaule) grain, extrudate and bran. Plant Foods for Human Nutrition (Dordrecht, Netherlands), 64(2), 94-101. https://doi.org/10.1007/s11130-009-0109-0.

Saalia, F. K., \& Phillips, R. D. (2011). Degradation of aflatoxins by extrusion cooking: Effects on nutritional quality of extrudates. Lebensmittel-Wissenschaft Und Technologie [Food Science and Technology], 44(6), 1496-1501. https://doi.org/1 0.1016/j.Iwt.2011.01.021.

Saeleaw, M., Dürrschmid, K., \& Schleining, G. (2012). The effect of extrusion conditions on mechanical-sound and sensory evaluation of rye expanded snack. Journal of Food Engineering, 110(4), 532-540. https://doi.org/10.1016/j. jfoodeng.2012.01.002.

Salfinger Y., and Tortorello M.L., 2015, Compendium of Methods for the Microbiological Examination of Foods, 5th Ed., American Public Health Association, Washington, D.C.

Salmerón-Manzano, E., Garrido-Cardenas, J. A., \& Manzano-Agugliaro, F. (2020) Worldwide research trends on medicinal plants. International Journal of Environmental Research and Public Health, 17(10), 3376. https://doi.org/10.33 90/ijerph17103376.

Sánchez-Moreno, C., Larrauri, J. A., \& Saura-Calixto, F. (1998). A procedure to measure the antiradical efficiency of polyphenols. Journal of the Science of Food and Agriculture, 76(2), 270-276 https://doi.org/10.1002/(sici)1097-0010(1 99802)76:2<270::aid-jsfa945>3.0.co;2-9.

Santana, A. L., Zabot, G. L., Osorio-Tobón, J. F., Johner, J. C. F., Coelho, A. S., Schmiele, M., ... Meireles, M. A. A. (2017). Starch recovery from turmeric wastes using supercritical technology. Journal of Food Engineering, 214, 266276. https://doi.org/10.1016/j.jfoodeng.2017.07.010.

Shah, F.-U.-H., Sharif, M. K., Bashir, S., \& Ahsan, F. (2019). Role of healthy extruded snacks to mitigate malnutrition. Food Reviews International, 35(4), 299-323. https://doi.org/10.1080/87559129.2018.1542534.

Shah, F.-U.-H., Sharif, M. K., Butt, M. S., \& Shahid, M. (2017). Development of protein, dietary fiber, and micronutrient enriched extruded corn snacks. Journal of Texture Studies, 48(3), 221-230. https://doi.org/10.1111/jtxs.12231.
Shruthi, V. H., Hiregoudar, S., \& Nidoni, U. (2019). Evaluation of textural properties of corn based extruded products. Plant Archives, 19(2), 2405-2410.

Singkhornart, S., Edou-ondo, S., \& Ryu, G.H. (2014). Influence of germination and extrusion with $\mathrm{CO}(2)$ injection on physicochemical properties of wheat extrudates. Food Chemistry, 143, 122-131. https://doi.org/10.1016/j. foodchem.2013.07.102

Singleton, V. L., Orthofer, R., \& Lamuela-Raventós, R. M. (1999). Analysis of total phenols and other oxidation substrates and antioxidants by means of folinciocalteu reagent. Methods in Enzymology, 299, 152-178. https://doi.org/10.1 016/S0076-6879(99)99017-1.

Sorolla, M. A., Rodríguez-Colman, M. J., Tamarit, J., Ortega, Z., Lucas, J. J., Ferrer, I., ... Cabiscol, E. (2010). Protein oxidation in Huntington disease affects energy production and vitamin B6 metabolism. Free Radical Biology \& Medicine, 49(4), 612-621. https://doi.org/10.1016/j.freeradbiomed.2010.05.016.

Statistical Analysis System [SAS] (2017). User's quide. Statistic. Cary, NC: SAS Institute Inc.

Stone, M. S., Martyn, L., \& Weaver, C. M. (2016). Potassium intake, bioavailability, hypertension, and glucose control. Nutrients, 8(7), 444. https://doi.org/10.33 90/nu8070444.

Syed, A., Naik, H. R., \& Hussain, Z. S. (2019). Storage stability studies of corn based rice bran incorporated extruded snacks. Journal of Pharmacognosy and Phytochemistry, 8(2), 492-494.

Tanweer, S., Shahzad, A., \& Ahmed, W. (2014). Compositional and mineral profiling of zingiber officinale. Pakistan Journal of Food Sciences, 24(1), 21-26.

Tejavathi, D. H., Sujatha, B. S., \& Karigar, C. S. (2020). Physicochemical properties of starch obtained from Curcuma karnatakensis - A new botanical source for high amylose content. Heliyon, 6(1), e03169. https://doi.org/10.1016/j.heliyon.2020.e03169.

Tohma, H., Gülçin, I., Bursal, E., Gören, A. C., Alwasel, S. H., \& Köksal, E. (2017). Antioxidant activity and phenolic compounds of ginger (Zingiber officinale Rosc.) determined by HPLC-MS/MS. Journal of Food Measurement \& Characterization, 11(2), 556-566. https://doi.org/10.1007/s11694-016-9423-z.

Turner, R. (1995). BottomLine in feed processing: Achieving optimum pellet quality. Feed Management, 46(12), 30-33.

Vega-Gálvez, A., Ah-Hen, K., Chacana, M., Vergara, J., Martínez-Monzó, J., GarcíaSegovia, P., ... Di Scala, K. (2012). Effect of temperature and air velocity on drying kinetics, antioxidant capacity, total phenolic content, colour, texture and microstructure of apple (var. granny smith) slices. Food Chemistry, 132(1), 51-59. https://doi.org/10.1016/j.foodchem.2011.10.029.

Vijayarani, D., Ponnalaghu, S., \& Rajathivya, J. (2012). Development of value added extruded product using Spirulina. International Journal of Health Sciences and Research, 2(4), 42-47.

Wani, S. A., Bhat, T. A., Ganie, N. A., \& Kumar, P. (2020). Impact of storage and packaging material on the nutritional, product properties and microbial count of extruded snacks. Current Nutrition and Food Science, 16(4), 592-600. https://doi.org/10.2174/1573401315666190126114847.

WHO (2019). global report on traditional and complementary medicine. Geneva: World Health Organization Licence: CC BY-NC-SA 3.0 IGO.

Wójtowicz, A., Lisiecka, K., Mitrus, M., Nowak, G., Golian, M., Oniszczuk, A., .. Combrzyński, M. (2019). Physical properties and texture of gluten-free snacks supplemented with selected fruit additions. International Agrophysics, 4(33), 407-416. https://doi.org/10.31545/intagr/112563.

Yadav, U., Singh, R. R. B., \& Arora, S. (2018). Evaluation of quality changes in nutritionally enriched extruded snacks during storage. Journal of Food Science and Technology, 55(10), 3939-3948. https://doi.org/10.1007/s13197-018-3319-3.

Yang, P., Wang, H., Zhu, M., \& Ma, Y. (2020). Evaluation of extrusion temperatures, pelleting parameters, and vitamin forms on vitamin stability in feed. Animals: An Open Access Journal from MDPI, 10(5), 894. https://doi.org/10.3390/ani10050894.

Zhishen, J., Mengcheng, T., \& Jianming, W. (1999). The determination of flavonoid contents in mulberry and their scavenging effects on superoxide radicals. Food Chemistry, 64(4), 555-559. https://doi.org/10.1016/s0308-8146(98)00102-2

\section{Publisher's Note}

Springer Nature remains neutral with regard to jurisdictional claims in published maps and institutional affiliations. 